Fırat Üniversitesi Sosyal Bilimler Dergisi

Firat University Journal of Social Science

Cilt: 25, Say1: 2, Sayfa: 249-268, ELAZIĞ-2015

\title{
OSMANLI-İRAN SINIR TESPITİ VE GÜVENLİĞİ AÇISINDAN BAZI AŞİRETLERİN ÇIKARDIĞI SORUNLAR (1850-1854)
}

\author{
Conflicts Caused By Certain Tribes on the Determination and Security of the \\ Ottoman-Iran Border (1850-1854)
}

\section{Sitkı ULUERLER ${ }^{1}$}

\section{ÖZET}

Osmanlı ve İran, XVI. yüzyılın başlarından itibaren pek çok anlaşmazlık dolayısıyla birbiriyle mücadele etmiştir. İki taraf arasında yüzyıllarca devam eden bu anlaşmazlık konularından biri de sınır boylarında yaşayan bazı aşiretlerin çıkardıkları sorunlar olmuştur. Bilhassa Van, Bayezid, Hakkâri, Musul, Süleymaniye ve Şehrizor gibi yerlerde bulunan bazı aşiretlerin göçebe yapıları, sosyal ve ekonomik durumları ile aşiret liderlerinin vasıfları, meydana gelen hadiselerin seyrini belirlemiştir.

Bahsi geçen bölgelerdeki aşiretlerin çoğunluğunun yaylak-kışlak dolayısıyla göçebe yaşamları ve buna bağlı olarak iki devlet topraklarına gidiş gelişleri, bu mevkilerde yaşayan yerleşik ahali üzerinde olumsuz tesirler meydana getirmiştir. Bu çerçevede bazı aşiretlerin Osmanlı ve İran topraklarında yağma, gasp, hırsızlık, adam öldürme gibi huzur ve asayişi bozucu tavırları, sıkça rastlanan vakalar halini almıştır. XIX. yüzyılın ilk yarısından itibaren sorunların daha da artması göçebe aşiretler meselenin iki devlet açısından ne kadar büyük bir sorun oluşturduğunu göstermiştir.

Aşiretler meselesinin Osmanlı ve İran üzerinde olumsuz neticeler doğurması dolayısıyla da, 1847 tarihinde imzalanan Erzurum Antlaşması'nın sekizinci maddesi bu konuya ayrılmıştır. Bu maddeye göre; sınır güvenliği ve huzurun tesis edilmesi başta olmak üzere, asayişin sağlanması, hangi aşiretin hangi devlete bağlılı̆̆ının tespit edilmesi gibi hususlar üzerinde durulmuştur. Ancak antlaşma sonrası Osmanlı-İran sınır tespitinden, bazı aşiretlerin hangi devlete bağlılığına kadar pek çok konu, hem çözümsüzlüğün hem de gerginliğin ana gündemlerinden biri olmaya devam etmiştir. Buna bağlı olarak 1850-1854 yılları arasında Osmanlı-İran sınır bölgelerinde bazı aşiretlerin karıştı̆̆ olayların mahiyetine bakıldığında meselenin öyle kolay hallolmayacağ da belli olmuştur.

Anahtar Kelimeler: Osmanlı, İran, Aşiretler

\section{ABSTRACT}

Ottomans and Iran struggled with each other starting from the early $16^{\text {th }}$ Century based on several conflicts. One of the items of conflict that lasted for centuries was the trouble caused by the tribes that lived on the borderline. Nomadic structure of the tribes living around the cities of Van, Bayezid, Hakkari, Musul, Süleymaniye and Şehrizor, their social and economical conditions and the qualities of tribal leaders defined the course of the events.

Nomadic lifestyle of the majority of the tribes of the area due to their seasonal movements between winter and summer quarters, and resulting movements across the country borders created negative effects on the non-migratory local people of the region. Their actions disturbing the public order and peace on Ottoman and Iranian lands such as pillage, usurpation, robbery and murder became common. Increasing troubles by the first half of the $19^{\text {th }}$ Century demonstrated how significant the nomadic tribes problem was for both countries.

Due to the negative results of tribal issues on both Ottomans and Iran, $8^{\text {th }}$ clause of the Erzurum Treaty signed in 1847 was spared for this conflict. The clause dealt with mainly establishing border security and peace, securing public order and determination of the loyalties of different tribes to either Turkey or Iran. However, even after the treaty several issues such as the determination of Ottoman-Iran borders and the loyalties of several tribes continued to be the main topics of both the deadlock and conflict between these two

\footnotetext{
${ }^{1}$ Yrd. Doç. Dr., Bingöl Üniversitesi, Fen-Edebiyat Fakültesi, Tarih Bölümü-BİNGÖL Mail:suluerler@bingol.edu.tr
} 
states. Consequently, a review of the events the border tribes involved in the Ottoman-Iran border region during 1850-1854 would demonstrate that the conflict would not be resolved easily.

Key words: Ottoman, Iran, Tribes

\section{GíRiş}

Osmanlı-İran ilişkilerinin tarihi evveliyatına bakıldığında iki taraf arasında var olan çekişme konuları ve anlaşmazlık hususlarının çok boyutlu olduğu görülmektedir. Safevîlerin devlet olarak XVI. Yüzyıl başlarında ortaya çıkmasından sonraki süreçte Osmanl1-İ́ran münasebetlerinde belli başlı çatışma konuları; başta siyasi hâkimiyet alanı mücadelesi olmak üzere, dinî/mezhebî anlaşmazlıklardan, sınır meselelerine, Irak-1 Arab toprakları üzerindeki nüfuz mücadelesine kadar çeşitli hususiyetler taşıdığı da belli olmaktadır. Bu bağlamda, özellikle iki devlet arasındaki mevcut uzun sınır boylarının; coğrafi, siyasi, sosyal, ekonomik ve nüfus durumu göz önünde bulundurulduğunda, bu bölgede bulunan aşiretlerin önemli birimler olduğu da görülmektedir.

Aşiretlerin kendine has yapıları, ağanın aşiret üzerindeki güçlü konumu, yüzyıllardır süre gelen aşiretlerin kültürel anlayışı ve ekonomik faaliyet alanları, aşiret gerçeğinin belli başlı yönleridir. Ayrıca aşiretlerin gerek varlıklarını sürdürmede ve gerekse bulundukları yerlerdeki hadiselerin şekillenmesindeki etkinlikleri göz önünde bulundurulduğunda bunların aynı zamanda Osmanl-İ́ran ilişkileri sürecinde özellikle de anlaşmazlık ve tartışma konularında önemli unsurlar olduklarını ortaya koymaktadır. ${ }^{2}$ Osmanl1-İran sınır bölgelerinde bilhassa Van, Bâyezîd, Hakkâri, Süleymaniye, Musul, Şehrizor gibi yerlerde sakin olan aşiretlerin pek çoğunun yaylak ve kışlak münasebetiyle Osmanlı ve İran topraklarına gidiş gelişleri söz konusudur. ${ }^{3}$ Aşiretlerin bu hareketlilikleri bağlamında çıkardıkları sorunların en önde gelenleri olarak görülen yağma, talan, gasp, adam öldürme vb. uygunsuz davranışlar iki devlet ilişkilerinin tarih boyunca gerginleşmesindeki önemli sebepler arasında görülmektedir.

Osmanl1-İran ilişkilerinde tarih boyunca yaşanan gerginlik konularının devam ettiği göz önünde tutulduğunda, Osmanlı'nın her zaman için Batı'da uğraştığı sorunlar yanında doğuyla da ilgilenmesini ne kadar zaruri olduğu anlaşılmaktadır. Nitekim XVIII. yüzyılın sonu ve XIX. yüzyılın başı itibariyle Osmanlı Devleti'nin buhranlı bir vaziyette olduğu ortaya çıkan gelişmelerden anlaşılmaktadır. Bu dönemde Batılı devletlerle yaşanan çekişmeler, İngiltere, Fransa ve Avusturya'nın Osmanlı'ya ilişkin hesapları, Rusya ile yapılan savaşlar ve alınan mağlubiyetler, elden çıkan topraklar, devletin merkezi yönetimindeki bozulma, ayanlar sorunu ve yenileşme çabaları gibi pek çok mesele Osmanlı için sıkıntılı bir devrin yaşandığının kanıtı niteliğindedir. ${ }^{4}$

Aynı dönemde İran'da da -Osmanlı kadar geniş çaplı olmamakla birlikte- büyük problemlerin yaşandığı ve en başta Rusya tehdidinin söz konusu olduğu düşünüldüğünde iki devletin benzer meselelerle uğraşmak zorunda olduğu görülmektedir. ${ }^{5}$ Hal böyle iken Osmanlı ve İran'ın kendi içinde öteden beri devam eden sorunlar çerçevesinde gerginlik durumunu devam ettirmeleri ve bu gerginlikte de aşiretler meselesinin yine önemli bir unsur olması, mevzunun anlaşılması açısından önem oluşturmaktadır. ${ }^{6}$

Esasında bu noktada üzerinde durmak istediğimiz husus, 1850-1854 yılları arasında Osmanl1İran gerginlik konuları ve o dönemde yürütülen sınır tespiti çalışmaları sürecinde ${ }^{7}$, iki devletin sınırlarındaki bazı aşiretlerin çıkardığı olayların yansımalarını ele almaktır. Zira bu döneme ilişkin Başbakanlık Osmanlı Arşivi'nde epeyce belge ve bilgi bulunmaktadır. Bu belgeler incelendiğginde

\footnotetext{
${ }^{2}$ Ramazan Balcı, Osmanlı'nın Doğu Siyaseti, Yitik Hazine Yay., İstanbul, 2010, s. 71-74.

${ }^{3}$ Bahsi geçen yerlerdeki aşiretler ve bunlar hakkında detaylı bilgi için bkz. Mehmed Hurşid Paşa, Seyâhatnâme-i Hudûd, Çevrimyazı, Alâattin Eser, Simurg Yay., İstanbul, 1997, s. 168-266.

${ }^{4}$ Mithat Sertoğlu; Mufassal Osmanlı Tarihi, C. V, TTK. Yay, Ankara 2011, s. 2683-2884.

${ }^{5}$ P. M. Sykes, A History of Persia, Vol., II, London, 1905, s. 410-414.

${ }^{6}$ Mirza Bala, "Kaçar" maddesi, İslâm Ansiklopedisi (MEB), C. VI, Eskişehir, 1997, s. 36-38.

${ }^{7}$ İbrahim Aykun, Erzurum Konferansı (1843-1847) ve Osmanll-İran Hudut Antlaşması, Basılmamış Doktora Tezi, Atatürk Üniversitesi, Sosyal Bilimler Enstitüsü, Erzurum 1995, s. 92-180.
} 
sorunların hangi boyutlarda olduğu, aşiretler meselesinin oluşturduğu algı, iki devletin kendi siyasi hesapları ve önceliklerinde aşiretler mevzusunu değerlendiriş biçimi ile yaylak kışlak münasebetiyle iki devlet topraklarına gidip gelen aşiretlerin çıkardıkları olayların mahiyeti daha net anlaşılmaktadır.

Aşiretler meselesinin aslında çok içe içe geçmiş sorunlar halini aldığı, asayiş, sınır güvenliği, iki devlet topraklarındaki yerleşik ahalinin yaşadığı yağma, talan, gasp, adam öldürme gibi olumsuz tarafları bulunduğu tarihi bir vakıadır. Bunun yanında Osmanlı ve İran'ın sınırlarının belirlenmesi sürecinde iki devletin tezlerine dayanak oluşturma adına, bu aşiretleri kendisinden gösterme çabalarının olduğu da düşünüldüğünde mevzunun ne kadar karışık bir hal aldığg da belli olmaktadır. Tüm bu yönler göz önünde tutulduğu vakit, aşiretler konusunun her zaman için iki devlet arasında ciddi bir mesele olarak kalacağını belli etmesinin ötesinde, yaşanan olumsuz hadiselerin iki devlet toprağında yaşayan ahaliyi ne kadar tedirgin ettiği de anlaşılmaktadır.

\section{Yüzyılın ilk Yarısında Aşiretlerin Osmanlı-İran İlişskilerindeki Yeri}

Aşiretler konusuna ilişkin sürecin anlaşılması açısından XIX. yüzyılın başı itibariyle Osmanlıİran gerginliklerine bakıldığında önemli ayrıntılar karşımıza çıkmaktadır. Ahmed Cevdet Paşa, Tarihi'nde 1236 (1820-1821) senesine ait vakaları anlatılırken; İran'ın, o siralar Osmanlı Devleti'nin Rum isyanı başta olmak üzere Batı'da yaşadığı sorunları bir firsat olarak değerlendirme yoluna gittiğini belirtmiştir. $\mathrm{Bu}$ hal dolayısıyla da Osmanlı yönetimi, doğuda olası bir yeni sıkıntının önüne geçme adına, İran sınırında bazı tedbirler alma yoluna gitmiştir. Ancak bu sınır bölgesinin en önemli sorunu olan ve iki devlet arasındaki kadim anlaşmazlık konularından birini oluşturan aşiretler meselesinin, öyle kolayca çözümlenecek bir mesele olmadığı yaşanan hadiselerden belli olmuştur. ${ }^{8}$

Nitekim Osmanl1-İran sınır bölgelerinde bulunan aşiretlerin yüzyıllardır devam eden yaylak ve kışlak dolayısıyla iki taraf toprağına gidiş gelişleri söz konusu olurken, bu aşiretlerin hangi devlete bağlı oldukları meselesi de her zaman için belli başlı tartışma mevzuları arasında yer almıştır. Aşiretlerin aynı zamanda uygunsuz hareketleri, gittikleri yerlerdeki yerleşik ahaliye zarar vermeleri; gasp, yağma, hayvan çalma, adam öldürme vb. gibi hallerinin çokluğu sıradan vakalar haline gelmiştir. ${ }^{10}$ Her vakit yaşanan bu tür olumsuz hadiseler iki devlet arasındaki gerginliklerin ana gündem konularından birini oluşturmuştur. ${ }^{11}$ Hatta kimi zaman Osmanlı-İran savaşının çıkma sebeplerinden biri haline gelen aşiretler mevzusu, tarihi süreçte önemini ve sorunlu halini sürdüren bir mesele olmaktan geri kalmamıştır. Tarihlerimize son Osmanl-İ́ran harbi olarak geçen 1821 yılında başlayan savaşın en önemli sebeplerinden biri de Haydaranlı Aşireti meselesi olması, konunun anlaşılması açısından önemli bir ayrıntıyı meydana getirmiştir. ${ }^{12}$

Bahsi geçen Osmanlı-İran harbinin çıkış sebepleri içerisinde doğu havalisindeki bazı Kürt aşiretlerinin İran askerine katılarak Kars Eyaletine bağlı Kağızman Sancağına tecavüz ile bölge ahalisinin hayvanlarını ve eşyalarını iki devlet arasındaki anlaşmalara aykırı bir biçimde gasp edip İran'a götürmeleri söz konusu olmuştur. ${ }^{13}$ Yine Bâyezîd ahalisinin bazı emval ve eşyasının kervan ile Erzurum'a gelişleri sırasında Revan Eyaleti dâhilinde bulunan Hacı Bayram isimli köy yakınlarında, Zilânlı Hasan Ağa’nın üç yüzden fazla süvarisi ve piyadesiyle bir miktar İran süvarisi kervana saldırmıştır. $\mathrm{Bu}$ saldırı neticesinde kervanda bulunan bazı kişilerin yaralanması ve bazısının da öldürmesinin dışında, kervandaki mal ve hayvanlar gasp edilmiştir. Hatta kervandaki

\footnotetext{
${ }^{8}$ Ahmed Cevdet Paşa, Tarih-i Cevdet, C. XII, Tertib-i Cedid, Dersa'adet, 1309, s. 4.

${ }^{9}$ Şânîzâde Mehmed Atâullah Efendi; Tarih-i Şânîzâde, C. III, İstanbul 1290, s. 144-146.

${ }^{10}$ Başbakanlık Osmanlı Arşivi (BOA), Hatt-ı Hümâyûn Tasnifi (H.H.), Dosya No: 4, Gömlek No: 105.

${ }^{11}$ Sitkı Uluerler; XIX. Yüzyıl İlk Yarısında Osmanlı-İran Siyasi İlişsileri (1747-1848), Basılmamış Doktora Tezi, Fırat

Üniversitesi, Sosyal Bilimler Enstitüsü, Elazığ, 2009, s. 269-275.

${ }^{12}$ Geniş bilgi için bkz. Sttk1 Uluerler; a.g.t., s. 279-285.

${ }^{13}$ BOA., H. H., D. No: 1, G. No: 8.
} 


\section{F.Ü. Sosyal Bilimler Dergisi 2015-25/2}

üç yük tüccar malı Revan kalesine naklettirilmiştir. Ayrıca Celâlî aşireti mensuplarının İncesu, Ortaköy, Başköy ve sair altı köy ahalisinin davarlarını sürüp götürdükleri de belirtilmiştir. ${ }^{14}$

İki devlet arasındaki hudutlarda aşiretlerin karıştı̆̆ tarafı da rahatsız ettiği ve pek çok gerginliğe sebep olduğu tarihi bir vakıa olmakla birlikte, bu durumun engellenmesinin pek mümkün olmadığı da o zamana kadar geçen hadiselerden anlaşılmaktadır. Durumun farkında olan ve her halükârda olan bitenlerden rahatsız olan Osmanlı ve İran yönetimleri, aşiretlerin çıkardığı bu tür hadiselerin yaşanmaması adına görünürde bir irade ortaya koymaya çalışmışlardır. Nitekim Osmanlı tarafından 1820 tarihinde İran'a gönderilen Tezkire-i Evvel Süleyman Hadî Efendi'ye, İran Şah'1 Feth Ali Şah'ın ifade ettiği;" hudud-ı hâkaniyeye tecavüz ve tahattî hususuna kendüsünün kat'en rizasi olmayub beyne'l-devleteyn mün 'akid olan şerâ 'it-i müsâlemenin devâmı..." hususuna dikkat çekmesi önemli bir noktadır. ${ }^{15}$

$\mathrm{Bu}$ ifadelerden de anlaşılacağı üzere İran tarafi, sınırdaki kendi aşiretlerinin çıkarmış olduğu sorunlar ve bu zümrelerin Osmanlı sınırına yönelik asayiş bozucu hareketlerinden duyduğu rahatsızlığı beyan ederek, iki devlet arasındaki barış durumu ve bunun şartlarının yerine getirilmesi konusundaki tavrını belli etmektedir. Ancak bazı aşiretlerin karıştı̆ $\breve{g}_{1}$ bu tip olumsuz hadiselerin sadece İran'a ait aşiretlerle alakalı olmadığı, Osmanlı tarafındaki bazı aşiretlerin de benzer tavırlar sergilediği göz önünde bulundurulduğunda, meselenin iki devlet için doğurduğu sıkıntılar daha net ortaya çıkmaktadır.

Tarihi süreçte Kars, Hakkâri, Van, Bâyezîd, Süleymaniye, Musul vb. gibi yerlerde bulunan pek çok aşiretin göçebe özellikleri ile buna bağlı olarak Osmanl1-İran topraklarındaki hareketlilik (yaylak-kışlak) halleri, bu mevkiler başta olmak üzere geniş bir alanda sıkıntıların baş göstermesine sebebiyet vermiştir. Yaşanan her olumsuz durum sonrasında Osmanlı yönetimi, yerel idarecileri uyarıp tedbirler almalarını istemekle birlikte, Osmanlı toprağına geçip eşkıyalık yapanların def' $i$ tenkili noktasında kararlı bir tutum izlemeleri noktasında da sınır bölgelerindeki idarecileri uyarmaktan geri durmamıştır. ${ }^{16}$

II. Mahmud döneminde (1808-1839) Osmanlı merkezi idaresini güçlendirme adına ortaya konulan devlet politikası çerçevesinde yerel güçlerin (ayan, mütegallibe) etkinliğini kırma adına hareket edilmesinin, bahsi geçen Osmanl1-İran sınır bölgesi üzerindeki aşiretler üzerinde de etkili olduğu görülmüştür. Merkeziyetçi yapıyı tesis etme adına sert tedbirler alan Osmanlı yönetiminin taşralarda bulunan sözü dinlenir, muktedir adamları haklılığına veya haksızlığına bakmaksızın birer bahane ile idam ya da sürgün etmesi, devlet siyasetindeki uygulama yanlışının bir başka cephesini oluşturmuştur. Zira Osmanlı-İran sınır bölgesinde bulunan aşiret, kabile reisleri/ağaları Osmanlı'nın bu uygulamasından duydukları rahatsızlık ve ortaya çıkan korku dolayısıyla İran'a yakınlık duyunca Osmanlı aleyhine dönüşen bir durumun yaşanmasına sebebiyet vermişlerdir. Ahmed Cevdet Paşa'nın bu husustaki tespitleri çok önemli olup, kendi ifadeleri ile bu vaziyeti Tarihi'nde şöyle ifade etmiştir. “... ol vakit Iran'ın hali daha karlşık ve idaresi daha bozuk ise de aşiret bĕ̆ ve ağalarına İran'ın muamelesi daha hoş görünüyordu. Zira İranlu bu rüesâya ağır hediyeler verirdi ve sonra bir kaç katını onların vasıtasıyla aşiretlerinden alırdı..., ,17

$\mathrm{Bu}$ çerçevede Osmanl1-İran ilişkilerinin tarihi seyrine baktığımızda sınır boylarındaki aşiretler meselesi hiçbir zaman için son bulmamış ve huzur tesis edilememiştir. Bilhassa iki devlet hudutlarında bulunan bazı Kürt aşiretlerinin durumu, bunların çıkardıkları problemler ve devrin şartlarına göre menfaatleri doğrultusunda ya İran ya da Osmanlı yanına geçmeleri halinin devamlılığı söz konusu olmuştur. Bu hadiseler önceki dönemlerde olduğu gibi XIX. yüzyılın ilk yarısı itibariyle de her zaman için karşımıza çıkan en önemli meseleler halini almıştır. Özellikle

\footnotetext{
${ }^{14}$ BOA., H. H., D. No: 1314, G. No: 51256; A. Cevdet Paşa, a.g.e., C, XII, s, 5.

${ }^{15}$ A. Cevdet Paşa, a.g.e., C, XII, s, 6.

${ }^{16}$ BOA., H. H., D. No: 444, G. No: 22247.

${ }^{17}$ A. Cevdet Paşa, a.g.e., C, XII, s, 7.
} 
bahsi geçen hudut üzerindeki aşiretlerin birbirlerine karşı husumet içeren tutumları ve saldırıları, iki devlet arasındaki sınır güvenliğini ciddi anlamda tehdit eden bir duruma dönüşmüştür. ${ }^{18}$

Osmanl1-İran gerginliklerinin 1843-1847 y1lları arasındaki mahiyeti ve meydana gelen problemlerin çözümü noktasında İngiltere ve Rusya'nın da aktif bir şekilde yer alıp sınır ihtilaflarının çözümünde üstlenmiş olduğu roller göz önünde tutulduğunda, problemlerden biri olan aşiretler konusunun hiç bir zaman için önemini kaybetmeyeceği ortaya çıkmıştır. Zira dört devlet (Osmanlı, İran, İngiltere ve Rusya) temsilcisinin görev aldığı hudut komisyonu çalışmaları bağlamında yürütülen müzakereler neticesinde, en sorunlu konulardan birinin aşiretlerin durumu hususunun olduğu da açıkça kendini belli etmiştir. ${ }^{19}$

Uzun görüşmelerden sonra 1847 tarihinde imzalanan Erzurum Antlaşması'nın sekizinci maddesi açık bir şekilde aşiretler meselesine ayrılmıştır. Bu maddenin içeriği şudur: "Antlaşmayı yapan Osmanll ve Iran, kendilerine bağll assiret ve kabilelerin iki devletin sinırında gasb u garet ve nehb-u sirkât (gasp, yağma, çapul, hirsızlık,) gibi harekete girişmelerini men 'etmek üzere gerekli tedbirlerin alınmasinı taahhüd eder. Bunun gerçekleştirilmesi için münasip mahallere asker ikâme edilmesi gerekmektedir. Bundan sonra iki taraf aşiretinden gasp, yağma ve katliam gibi tecavüzî bir hareket vuku bulursa bundan o aşiretin bağlı bulunduğu taraf sorumlu olacaktır. Hangi tarafa bağgl oldukları belirsiz olan aşirete bundan sonra daimi olarak ikamet edecekleri yerleri seçmeleri hususu bir kereye mahsus kendi rey ve irâde-i ihtiyarilerine havale olunacaktır. Tebaiyetleri (bağlllıklart) belli olan aşiretlerin tabi oldukları devletin arazisine cebren de olsa girmeleri sağlanacaktır. ${ }^{, 20}$

$\mathrm{Bu}$ madde çerçevesinde aşiretlerle alakalı sorunların ne olduğu açıkça kendini göstermektedir. Bunlardan ilki, iki devlet hududunda -gerek İran'a ve gerekse Osmanlı'ya bağlı olsun- bazı aşiretlerin sürekli olarak gasp, yağma, hırsızlık, katliam vb. benzer asayişi bozucu güvenliği tehdit eden davranışlarını sürdürmeleridir. Doğal olarak bu tür hadiseler hangi taraf aşireti vasıtasıyla yapılırsa yapılsın diğer tarafın tepki vermesi ve yapılanların hesabının sorulmasını istemesi en doğal talep olmakla birlikte, bu tip hadiselerin önüne geçilmesi açısından da sınırlardaki uygun yerlere Osmanlı ve İran devletlerinin asker yerleştirmesi bir çeşit çözüm olarak görülmektedir. Bundan sonra hangi taraf aşiretinden uygunsuz bir davranış söz konusu olursa o tarafın olanlardan mesul olmasının altı çizilmektedir.

Yine bu madde kapsamında aşiretlerle ilgili en temel sorunlardan biri de ortaya çıkmaktadır. Buna göre hangi aşiretin hangi devlete bağlı olduğu meselesi en tartışmalı konu mesabesindedir. Tarih boyunca bu havalinin kendine has coğrafi yapısı, nüfusu, aşiretlerin sosyolojik durumu, iki taraf topraklarına yaylak ve kışlak için gidiş gelişleri, aşiretlerin daimi olarak bir devlet tebaası olarak sayılmasını güçleştiren hususlar arasındadır. Ayrıca tarih içinde iki devletin içinde bulunduğu sorunlara göre aldığı tedbirler ve bu tedbirlerin aşiretler üzerindeki tesirleri göz önünde tutulduğunda, aşiretlerin hangi devlete bağlanacakları hususunun öyle kolayca çözülemeyeceği de ortaya çıkmaktadır. Nitekim yukarıda ifade ettiğimiz üzere II. Mahmud döneminde Osmanlı'nın merkezi otoriteyi güçlendirme çabası çerçevesinde aldığı tedbirler bağlamında, yerel güç unsurlarını etkisizleştirme hadisesinin Osmanlı-İran sınır bölgesindeki aşiret liderlerinde Osmanlı'dan korkup, İran tarafına meyletmesinin yolunu açmıştı. Yine İran tarafından baskıya maruz kalan aşiretlerin Osmanlı tarafına geçtikleri de düşünüldüğünde, aşiretlerin hangi devlet tebaasından olacağı meselesinin kolay çözülecek bir mevzu olmadığı da açıktır.

Antlaşma maddesinin son bölümünde yer alan ve hangi tarafa bağl1lı̆̆ belli olmayan aşiretlerin bir kereye mahsus olmak üzere kendi rey ve iradeleri ile bir devlete bağlanmaya karar vermeleri konusunun da rahatlıkla çözümlenebilecek bir mesele olmadığı tarihi olayların akışından

\footnotetext{
${ }^{18}$ Muhammed Rıza Nasırî, Nâsıreddin Şah Zamanında Osmanlı-İran Münasebetleri (1848-1896) Basılmamış Doktora Tezi, İstanbul Üniversitesi Edebiyat Fakültesi, İstanbul 1977, s. 7-8.

${ }^{19}$ İ. Aykun, a.g.t., s. 56-86.

${ }^{20}$ BOA., A. DVN. MHM., D. No: 5, G. No: 35. Yine antlaşmanın maddeleri için ayrıca bkz. İbrahim Aykun, a.g.t., s. 242245; S. Uluerler, a.g.t., s. 465.
} 
anlaşılmaktadır. Zira günümüz mantığı ile bir halkoylaması şeklinde bir seçimin söz konusu olamayacağı bu belirleme işinde, aşiret liderlerinin en önemli aktörler olacağı aşikârdır. Osmanlı ile İran tarafının da kendi çıkarları doğrultusunda bu aşiret liderleri üzerinde etki oluşturacağı muhakkaktı. Yine antlaşma maddesinde yer alan Osmanlı veya İran'a bağlılıkları belli olan aşiretlerin cebren de olsa bağlı bulundukları devletin topraklarına gitmeleri mecburiyeti de uygulamada sorun doğuracak bir husustu. Çünkü bu aşiretler, göçebelik çerçevesinde iki taraf toprağına da gidip gelen ve bunu geleneksel yapıları içerisinde vazgeçilmez bir durum olarak kabul eden gruplardı. Yani bir aşirete sen Osmanlı aşiretisin bütün aşiret halkını Osmanlı toprağına getireceksin ve asla İran tarafina geçmeyeceksin demenin veya aynı şekilde İran aşiretine de benzer bir şeyi benimsetmenin reel politikte uygulanabilirliği mümkün değildi.

Kısacası 1847 tarihli Erzurum Antlaşması, iki devlet arasında kabul edilen kalıcı bir barış antlaşmasına dönüşememiştir. $\mathrm{Bu}$ antlaşmanın, başta sınırların tespiti ve ihtilaflı yerlerin çözümü meseleleri olmak üzere önemli mevzuları halledememesi, bu sorunların kurulacak bir komisyon vasıtasıyla sonraki dönemlere bırakması dolayısıyla problemli halini sürdürmüştür. İran'da 1848 senesinde başa geçen Nâsıreddîn Şah zamanında Erzurum Antlaşmasının üçüncü maddesi çerçevesinde Osmanl1-İran hudut meselesinin halli için iki devlet temsilcileri ile İngiltere ve Rusya'nın tayin ettikleri gözlemcilerle Bağdat'ta sınır komisyonunun toplanmas1 kararlaştırılmıştır. ${ }^{21}$ Ancak Osmanlı elinde bulunan Kotur'un konumu ve buraya ilişkin İran'ın kendisine ait olduğu iddiaları çerçevesinde komisyonun çalışmalarına başlaması gecikmiştir. ${ }^{22}$

Esasında iki taraf arasındaki anlaşmazlıkların çok cepheli olması çözümsüzlüğü tetikleyen hususlar olmakla birlikte, esas konumuz olan bu süreçte aşiretlerin durumu ve iki devlet arasında oluşturduğu problemin mahiyetine de dikkat etmek gerekmektedir. Sürece baktığımızda başta hudut tespiti mevzusu olmak üzere Osmanlı-İran ilişkilerinin bütün tarihi arka planı noktasında bu meselenin önemli yer tuttuğu da bir hakikattir. Meselenin; güvenlik, asayiş, sınır tespiti boyutlarının yanında Osmanlı ile İran'ın kendi öncelikleri ve hassasiyetleri belli bir yer tutmaktadır. İki devletin sınır bölgesinde bulunan göçebe aşiretlerin ekseriyetinin Kürt olması, bu zümrelerin yaşayış özellikleri, aşiret bağları, aşiret lider ve ağalarının tutumu, kadim anlaşmazlık konuları, yaylak ve kışlak gidiş gelişleri gibi daha da arttıracağımız hususlar mevzunun başka yönlerini meydana getirmektedir. Bu çerçevede yaşanan gerginliklerin XIX. yüzyılın ikinci yarısı baş1 itibariyle bilhassa Osmanlı arşiv belgelerine yansıdığı şekliyle hangi boyutlarda olduğu ve Osmanlı yönetiminin nasıl bir bakış içerisinde olduğu bu çalışmamızın ana eksenini oluşturmaktadır.

\section{Osmanlı Yönetiminin Aşiretlerin Yaylak ve Kışlak Gidiş-Gelişlerine Yönelik Tavrı}

Osmanlı Devleti, İran ile arasında yürütülen sınır tespiti mevzusunun tartışmalı ve süreklilik arz ettiği sıralarda 1850 yılı itibariyle en azından sınırlarında aşiretlerin çıkardığı sorunların çözümü açısından ne gibi tedbirler alacağını gündemine almıştır. Osmanlı yönetimi, sorunun temelinde bu aşiretlerin iki taraf topraklarına da geçme hallerinin yüzyıllardır kendi geleneksel anlayışları ve ekonomik özellikleri bakımından vazgeçilmez bir durumdan kaynaklandığını göz önünde bulundurmuştur. Bu bağlamda en azından kendi sınırlarındaki aşiretlerin İran tarafına geçmelerinin engellenmesi ve İran aşiretlerinin de Osmanlı topraklarına gelmesinin yasaklanması için ne gibi adımlar atacağını kararlaştırmak istemiştir.

$\mathrm{Bu}$ çerçevede 1851 yılı bahar mevsimi itibariyle Bâyezîd hududuna dört saat mesafede bulunan, Hakkâri Eyaleti'ne tabi Mahmûdî bölgesine her sene yaz mevsiminde yaylak için epeyce İran aşiretinin geldiği ve bu aşiretlerin güz mevsiminde geri dönüp gittikleri belirtilmiştir. $\mathrm{Bu}$ çerçevede bu havaliye gelen İran aşiretlerinin burada bulundukları süre içerisinde bazı uygunsuz hareketlerde bulundukları, asayişsizlik hallerinin olduğu, Osmanlı tarafından yapılan araştırmalar sonucu ortaya çıkmıştır. Buna bağlı olarak da bu İran aşiretlerinin Osmanlı sınırına yönelik tecavüz

\footnotetext{
${ }^{21}$ Melike Sarıkçığlu, Osmanlı-İran Hudut Sorunları (1847-1913), TTK., Yay., Ankara, 2013, 67-70.

${ }^{22}$ M. R. Nasirî, a.g.t., s, 16-19.
} 
edici hareketlerinin iki devlet arasında var olan mevcut antlaşmalara aykırı bir durum oluşturduğu vurgusu yapılmıştır. Bu halin süreklilik göstermesi durumunda ileriki zamanlarda daha da büyük sıkıntıların kaçınılmaz olduğunun altını çizen Osmanlı yönetimi, aşiretlerin gelişini engelleme adına gerekli girişimlerde bulunmanın önemi üzerinde durmuştur. ${ }^{23}$

Konuya ilişkin olarak Meclis-i Vâlâ'da yapılan müzakereler sonrasında mevzubahis olan İran aşiretlerinin Mahmûdî sahrasına gelmelerinin engellenmesi noktasında gerekirse bu aşiretlerin geleceği bahar mevsiminde bu havaliye muvazzaf süvari asker yerleştirilmesi de gündeme alınmıştır. Esasında mecliste yapılan görüşmelerde Osmanlı ve İran aşiretlerinin geleneksel yapılarına ilişkin olarak yüzyıllardır sürdürdükleri yaylak-kışlak gidiş gelişlerinin vakıa olduğunun altı çizilmiştir. Hal böyle iken böyle bir tedbir alarak, aşiretlerin gelişinin engellenmesinin öyle kolay bir iş olmadığ 1 da ifade edilmiştir. Zira Osmanlı yönetimi, askeri tedbirlerle kendi topraklarına İran aşiretlerinin girişini engellemesi halinde, İran'ın da en azından misilleme kabilinden benzer bir yaptırımı Osmanlı aşiretlerine uygulamasının söz konusu olacağı vurgulanmıştır. İşte böyle bir vaziyette Osmanlı'nın kendi aşiretlerine yönelik nasıl bir çözüm yolu bulacă̆ 1 hususu tartışmaya açılmıştır. ${ }^{24}$

Bu çerçevede Osmanlı Devleti'nin sahip olduğu toprakların vasfı, büyüklüğü, iklim özellikleri, verimliliği gibi hususlardan bahsedildikten sonra, Osmanlı ülkesinde yaylak ve kışlağa uygun yerlerin İran'dan daha çok olduğu belirtilmiştir. Buna bağlı olarak da gerek Bâyezîd'de ${ }^{25}$ bulunan ve gerekse Bâyezîd çevresindeki havalide meskûn olan Osmanlı aşiretlerinden hiç birinin yaylakkışlak münasebetiyle İran tarafına gitmeye ihtiyacı olmadığ görüşü ortaya atılmıştır. Buna bağlı olarak da İran tarafında yaylak yerlerinin azlığı göz önünde bulundurulduğunda, İran'a bağlı aşiretlerin Osmanlı tarafına geçmelerinin engellenmesi halinde bu aşiretlerin yaşayacakları sıkıntı dolayısıyla Osmanlı'ya bağlanmaları durumlarının söz konusu olacağı ve bu aşiretlerin hane halklarıyla beraber Osmanlı tarafına geçmek isteyecekleri gündeme gelmiştir. Bundan dolayı da Meclis-i Vâlâ'da alınan karar doğrultusunda Osmanlı'nın askeri tedbir almasının yerinde olacağı, yani Osmanlı tarafına İran aşiretlerinin geçişinin yasaklanması görüşü ağırlık kazanmıştır. ${ }^{26}$

Yukarıda çerçevesi çizilen hususa ilişkin alınan karar Bâyezîd Sancağı Kaymakamı Feyzullah Efendi'ye bildirilmiştir. Osmanlı'nın İran aşiretlerinin bu tarafa geçişini engelleyici kararı sonrasında, İran'ın aynı yönde karşılık vereceğinden bahisle de Osmanlı aşiretlerinin gerek yaylak ve gerekse kışlak amacıyla İran tarafına gitme mecburiyetinden kurtarılması bağlamında alınacak tedbirlerin yerine getirilmesi istenmiştir. Bu çerçevede bahsi geçen havaliye yüz kadar muvazzaf süvari askerin gönderilmesi de kararlaştırılmıştır. Ayrıca o dönemde Zilân Aşireti Müdürü olan Kasım Ağa'nın bu konuya ilişkin olarak memur tayin edilmesi ve onun bu vazifeyi yerine getirmesinden şüphe edilmeyeceği de ifade edilmiştir. Bunlara ilave olarak Bâyezîd havalisindeki Osmanlı aşiretlerinin İran tarafına geçmeye mecbur olmadıklarının anlaşıldığı, ancak Van ve Hakkâri taraflarında olup da İran tarafina geçmeye mecbur durumda bulunan aşiretlerin olup olmadığının tespitinin yapılmasının gerekliliği vurgulanmıştır. Bu konuya ilişkin olarak da Hakkâri Valisi'nden kapsamlı bir rapor hazırlaması istenmiştir. Hakkâri Valisi'nden gelen bilgiler doğrultusunda kendi havalisinde de İran tarafina geçmeye muhtaç aşiretler bulunmadığı Van ve Hakkâri mıntıkalarının da Bâyezîd tarafina benzer özellikler taşıdığından bahisle, buradaki Osmanlı aşiretlerinin öte tarafa gitmemeleri halinde ciddi bir sorunla karşılaşmayacakları belirtilmiştir. ${ }^{27}$

\footnotetext{
${ }^{23}$ BOA., Irade Meclis-i Vâlâ (İ. MVL), D. No: 225, G. No: 7665, Belge No: 1. Bu arşiv vesikasındaki tarih 7 Cemaziyülevvel 1267 / 10 Mart 1851'dir.

${ }^{24}$ BOA., I. MVL., D. No: 225, G. No: 7665, Belge No: 1.

${ }^{25}$ Bâyezîd, konumu itibariyle, bir taraftan Van sancağı, diğer taraftan İran tasarrufunda bulunan Hoy hükümetine tabi Maku mahalli ile Rusya kontrolünde bulunan Revan'la çevrilidir. Bâyezîd, Erzurum Eyaletine tabidir. Bu havalinin belli başlı aşiretleri ise, Celâlî Aşireti, Haydaranlu Aşireti, Sebîkî Aşireti, Zilânlû Aşiretleridir. Bu aşiretlere ait de pek çok taife vardır. M. Hurşid Paşa, a.ge.,s. 259-263.

${ }^{26}$ BOA., I. MVL., D. No: 225, G. No: 7665, Belge No: 1.

${ }^{27}$ BOA., I. MVL., D. No: 225, G. No: 7665, Belge No: 3.
} 


\section{F.Ü. Sosyal Bilimler Dergisi 2015-25/2}

Meclis-i Vâlâ'da yapılan müzakereler sonrası ortaya çıkan sonuçtan anlaşılacağı üzere, Osmanlı-İran hudut tespiti çalışmaları ve tartışmaları bağlamında Osmanlı ve İran'ın birbirlerine karşı ileri sürdükleri tezler içerisinde aşiretlerin yeri ve sınır tespitindeki konumu, meselenin çok yönlü bir hal aldığına işaret etmiştir. Aşiretler meselesinin güvenlik, asayiş gibi yönleri bulunmakla birlikte, yukarıda belirttiğimiz Erzurum Antlaşması'nın sekizinci maddesi çerçevesinde bir aşiretin kendi iradesi ile bir tarafa bağlanması hususunun oluşturduğu esnek durum, aynı zamanda sınır tespitinde gerek nüfus ve gerekse aşiretlerin bağlı bulundukları devlet açısından o devlete bir fayda getireceği öngörüsünü de doğurmuştur. Nitekim Osmanlı yönetiminin Bâyezîd, Van ve Hakkâri dolaylarındaki kendi aşiretlerinin İran tarafına gitmelerini engellemek için ön hazırlık yapıp yerel idarecilerden raporlar almıştır. Bu bağlamda İran tarafından Osmanlı topraklarına yaylak için gelecek olan aşiretlerin engellenmesi durumunda İran'daki mevcut yaylak mıntıkalarının yetersizliği göz önünde bulundurularak, İran'a bağlı olan aşiretlerin kendi haneleri ile Osmanlı tarafına geçme isteğinin söz konusu olacağı vurgusu yapılmıştır. Yine Osmanlı aşiretlerinin İran tarafına geçmelerinin önüne geçmek için Osmanlı'ya bağlı olan Zilân aşireti Reisi Kasım Ağa'nın memur tayin edilmesi durumu da önemli bir ayrıntıyı oluşturmuştur.

Bu konu çerçevesinde 23 Muharrem 1268 / 18 Kasım 1851 tarihli Meclis-i Vâlâ toplantısında Erzurum Valisi'nin gönderdiği rapor doğrultusunda Bâyezîd sınırına yakın Mahmûdî sahrasının durumuna ilişkin bilgiler son haliyle tekrar ele alınmıştır. Gerek buraya asker gönderilip güvenliğinin sağlanması hususu ve gerekse Zilânlı Kasım Ağa'nın görevlendirilmesi konuları üzerinde durulmuştur. Bu noktada Bâyezîd Kaymakamı'ndan gelen yazıya da değinilmiştir. Bâyezîd Kaymakamı Feyzullah Efendi, Erzurum Valisi'ne gönderdiği yazısında Mahmûdî havalisinin Hakkâri Eyaleti dâhilinde bulunmasına bağlı olarak buranın güvenliğinin sağlanmasında yetkinin Hakkâri Valiliğine verilmesinin uygun olacağını ifade etmiştir. Ancak mecliste yapılan müzakereler sonrasında buraların kontrolünün Erzurum Valisi marifetiyle yapılmasının daha uygun olacağına karar verilmiştir. Neticede bu konuya ilişkin olarak ortaya çıkan kanaat; "vakı'a memalik-i Devlet-i Aliyye dâhilinde bulunan mahallere Iran 'aşaîrinin yaylakıye içün gelüb gitmelerinin men 'i hayırlu olduğundan ... böyle bir tedabir-i cüzi ile bu sûretin icrâsı kâbil olduğu halde bi'l-suhûlet matlûb hâsıl olacăgl " ifadeleriyle teyit edilmiştir. ${ }^{28}$

Osmanlı yönetimi, Mahmûdî havalisi başta olmak üzere bu mıntıkaların güvenliğinin sağlanması açısından öngörülen yüz kadar askerin istihdam edilmesinin yeterli olup olmayacağ1 meselesini de düşünmüştür. Hatta bu kadar askerin güvenliği sağlamaya kifayet etmeyeceği, İran aşiretlerinin zorla da olsa Osmanlı tarafina geçmeye yeltenebilecekleri ve Zilânlı Kasım Ağa'ya verilen görev dolayısıyla da onun aşiretine karşı İran aşiretlerinden bir saldırı olabileceği kuşkusu dile getirilmiştir. Ancak olası tüm bu olumsuzluklara rağmen, devletin alacağı tedbirlerle bunları engelleyebileceğinin altı çizilmiştir. ${ }^{29}$

Osmanlı Devleti, kendi aşiretlerinin İran tarafina gidişinin önüne geçilmesi ve İran aşiretlerinin bu tarafa gelmesinin yasaklanması hususunu bir başka cepheden de ele almak zorunda kalmıştır. Zira İran-Osmanlı hududu sadece Bâyezîd, Van ve Hakkâri ile sınırlı değildi. Bağdat taraflarının durumu ve buraya gelen İran aşiretleri de vardı. Özellikle Bağdat havalisi içerisinde bulunan İmadiye havalisinin arazi bakımından büyük oranda ziraata elverişli olması ve bu ziraat işleriyle de İran'dan gelen aşiretlerin ilgilenmesi söz konusuydu. Şayet buraya da İran aşiretlerinin gelmesi yasaklanırsa bu sefer de bu havalideki insanlar geçimlerini sağlamada sıkıntıya düşüp tümden buraları terk etme ihtimalleri vardı. Kısacası İmadiye sahrasının ekonomik ve sosyal yapısı bu aşiret hareketleriyle alakalıydı. Osmanlı yönetimi meselinin bu cephesini de göz önünde bulundurarak Hakkâri ve Erzurum valilerinin tekrar etraflı bir araştırma yapmalarını istemiştir. ${ }^{30}$

Sonuç itibariyle yapılan müzakereler ve alınan görüşler bağlamında, İran aşiretlerinin bilhassa Bâyezîd'deki Mahmûdî sahrasına gelmelerinin yasaklanması hususu 2 Aralık 1851 tarihi itibariyle

\footnotetext{
${ }^{28}$ BOA., I. MVL., D. No: 225, G. No: 7665, Belge No: 5.

${ }^{29}$ BOA., I. MVL., D. No: 225, G. No: 7665, Belge No: 5.

${ }^{30}$ BOA., I. MVL., D. No: 225, G. No: 7665, Belge No: 5.
} 
kararlaştırılmıştır. Bunun uygulamaya konulması için tarih olarak 1852 senesi bahar ayları belirlenmiştir. ${ }^{31}$ Ancak alınan kararı uygulamanın pek mümkün olmadığı, mevcut o bölgenin yapısı ve geleneksel aşiretlerin hareket durumlarıyla, Osmanl1-İran arasındaki sınır tespiti meselelerinin oluşturduğu gerginlik ortamı, sonraki süreçte de sıkıntıların devam edeceğini belli etmiştir.

\section{Şikâk Ali Ağa Meselesinin Osmanlı-İran Arasındaki Gerginlik Sorunu}

1851 senesi yaz aylarında yaşanmış olan Şikâk ${ }^{32}$ aşiretine ilişkin mesele, yukarıda belirttiğimiz ve Osmanlı yönetiminin tedbir amaçlı olarak uygulamak istediği iki taraf aşiretlerinin yaylak ve kışlak gidiş gelişlerinin engellenmesinin pek mümkün olmadığını gösteren önemli özellikler taşımaktadır. ${ }^{33}$

Öncelikle XIX. Yüzyılın ikinci yarısı itibariyle Şikâk aşireti hakkında Mehmed Hurşid Paşa'nın verdiği bilgilere bakacak olursak. Bu aşiretin bir kısmının Osmanlı'ya bağlı olarak Hakkâri ve Van çevresinde yaşadığı bir kısmının ise İran'da meskûn bulunduğu bilgisi vardır. Bu aşirete bağlı yedi taife vardır. Bunların isimleri; Avduyî, Henârciyî, Kardâr, Şerrâ, Bustâ, Küzkî, Kavânâ olup o zamanki toplam hane sayıları bin iki yüz elli adettir. Şikâk aşiretinden İran'a tabi olan taifeler Baradost, Somay taraflarında bulunmaktadır. İran'daki Şikâk aşireti sakinleri İran Devleti'ne yıllık olarak 1500 tümen akçe vergi vermektedirler. Kendilerinin İran taraflarında bulundukları mahallere İran Devleti asker sevk ettiği zaman, kendileri de istenilen kadar süvari asker vermek zorundadırlar. Bu taifelerin çoğunluğu hayme-nişinn (göçebe) olup dilleri Kürtçe, mezhepleri ise Şâfi'i'dir. ${ }^{34}$

Şikâk Aşiretinin büyük bir alana yayıldıkları göz önünde bulundurulduğunda, Osmanlı ve İran sınırı içerisinde geniş bir mıntıkada varlıklarını sürdürdükleri de anlaşılmaktadır. Hatta 1853 yılı itibariyle Osmanlı'nın tespitlerine göre iki bin beş yüz haneden oluşan bu aşiretin Musul, Revândız taraflarında kışlakları olduğu bilgisi de vardır. ${ }^{35}$ Yine bu aşiret hakkında Sykes'ın verdiği bilgilerde, altı bin aileden oluştuğu belirtilerek, Revan taraflarında bulundukları ve göçebe oldukları ifade edilmektedir. ${ }^{36}$ Açıkçası üç kaynakta bu aşirete ait farklı hane sayıları verilmesi, bu aşiretin büyüklügünün anlaşılmasının yanında farklı havalilerde bulunduklarını da göstermektedir.

Bahsi geçen bu aşiretin bulunduğu yerlerin Van ve Hakkâri havalisi içerisinde özellikle Van'a bağlı olan Ebgây (Ebâga/ Abâga) tarafları olup ${ }^{37}$ buraların çevresi Osmanl1-İran arasındaki sınır ihtilafları meselesi çerçevesinde tartışmalı yerlerden (münâza 'un-fih mahaller) olması durumu, iki devlet arasındaki aşiret sorunlarının en çarpıcı örneklerinden birini oluşturmuştur. 1851 senesinde, Şikâk aşireti Ağası olan Ali Ağa'nın uygunsuz davranışları ve İran tarafina verdiği zarar-ziyan dolayısıyla üzerine İran tarafindan asker sevk edilmiştir. Osmanlı yönetiminin aldığı istihbarat bilgilerine göre İran, iki tabur süvari asker tedarik ederek Şikâk Ali Ağa üzerine göndermiştir. Şikâk Ali Ağa taraftarı olan başıbozuk aşiret mensupları da üzerlerine gelen İran askerine uygun bir mahalde pusu kurarak yüz kadar İran süvarisinin üzerine karşı saldırıya geçmişlerdir. Bu çarpışma esnasında İran askerinden iki tanesi ölmüştür. Şikâk Ali Ağa da çatışma sırasında iki İran askerini yaralamıştır. Bu çarpışmalar devam ederken pusu kurulan yere yönelen diğer İran askerlerinin geldiğini gören Şikâk Ali Ağa zor durumda kalarak kaçmıştır. ${ }^{38}$

\footnotetext{
${ }^{31}$ BOA., I. MVL., D. No: 225, G. No: 7665, Belge No: 7.

${ }^{32} \mathrm{Bu}$ aşiretin ismine yönelik bazı okumalarda Şakâk/Şekâkî şekline de tesadüf edilmektedir. Mehmed Hurşid Paşa, a.g.e., s. 248.

33 BOA., A. MKT.UM., D. No: 62, G. No: 44.

${ }^{34}$ Mehmed Hurşid Paşa, a.g.e., s. 248.

${ }^{35}$ BOA., I. MVL., G. No: 11798 , B. No: I.

${ }^{36}$ Mark Sykes, "The Kurdish Tribes of the Ottoman Empire", The Journal of the Royal Anthropological Institute of Great Britain and Ireland, Vol. 38, Jul.-Dec., 1908, p. 461.

${ }^{37}$ Mehmed Hurşid Paşa, a.g.e., s. 232, 237.

${ }^{38}$ BOA., A. MKT.UM., D. No: 62, G. No: 44.
} 


\section{F.Ü. Sosyal Bilimler Dergisi 2015-25/2}

Canını zor kurtaran Şikâk Ali Ağa kendi yanındaki yüz kadar adamı ile Coni ${ }^{39}$ Kalesine sığınmıştır. Aynı zamanda Şikâk Ali Ağa, ailesinin başına bir şey gelmemesi için de onları Cari ${ }^{40}$ taraflarına göndermiştir. Şikâk Ali Ağa'nın sığındığı kaleden çıkarılıp yakalanması amacıyla da İran askerinin Urmiye'den iki top istediği bilgisi alınmıştır. Bu haberlerden rahatsız olan Osmanlı yönetimi, Şikâk Ali Ağa'nın konum itibariyle iki devlet arasında ihtilaflı olan mahaller mevkiinde olması dolayısıyla buraya İran'ın asker sevk etmeye hiçbir hakkı bulunmadığını belirtmiştir. Hatta Osmanlı Devleti, İran'ın bu tavrından duyduğu rahatsızlığ İran'ın bu hareketini mazbût mizaçlarından kaynaklandığına yorarak tepkisini ifade etmiştir. Ayrıca İran'ın böyle bir askeri hareket kapsamı içinde Osmanlı sınırlarını ihlal edici bir durumlarının olması halinde de Osmanlı'nın buna misliyle karşıllk vereceği tehdidinde bulunulmuştur. ${ }^{41}$

$\mathrm{Bu}$ hadisenin mahiyeti icabı aşiretler konusunda dikkatimizi çeken yönlerini ele alacak olursak, şunları belirtmek mümkündür. Öncelikle bahsettiğimiz Şikâk Ali Ağa meselesinin tek başına münferit bir hadise olmadığı ve buna benzer meselelerin her zaman için yaşanan sıradan mevzulardan olduğunu söyleyebiliriz. Görüldüğü üzere bu aşiretin bütünüyle ne İran ne de Osmanlı sınırları içerisinde olmadığını görmekteyiz. Aşiretin göçebe bir özellik taşıması ve bulundukları yerlerde -burası gerek Osmanlı toprağ 1 olsun gerekse de İran toprağı olsun fark etmiyor- problem çıkarıp asayişsizlik olaylarına karışmasının, hatta Şikâk Ali Ağa meselesinde olduğu gibi silahlı çatışmaya girilmesi durumunun söz konusu olduğu da anlaşılmaktadır. Ayrıca aşiretlerin farklı mevkilerde kollarının bulunması yine kendisine yakın gördükleri aşiretlerle olan irtibatları, sığınma ve yer değiştirme gibi hareket alanlarını da genişleten bir durumdur. Bunun yanında iki devletin birbirleriyle olan münasebetlerindeki gerginliklerin farkında olan aşiretlerin, karşı tarafta çıkaracağı sorun sebebiyle diğer devletten destek göreceği veya sahiplenileceği öngörüsü de vardır.

Bu noktada akla şöyle bir soru da gelmektedir. Bu meselede Osmanlı neden İran'a karşı sert bir tepki göstermektedir? Bunun cevabı olarak da şunu söylemek mümkündür. İki devlet arasında var olan hudut tespiti çerçevesinde aşiretler bir nevi hayati önem taşıyan unsurlar haline gelmişti. Bir devlet stratejik bir mevkiin kendisine ait olduğunu iddia ederken ve bunu gözlemci İngiltere ile Rusya gibi devletlere de kabul ettirmek isterken elindeki en önemli dayanak, o havalide oturan aşiretlerin öteden beri kendisine bağlı olduğunu ispatlamaktı. ${ }^{42}$

Bu tespitlerden sonra Şikâk Ali Ağa meselesinin devamına bakacak olursak. Osmanlı Devleti, İran askerinin bu mesele dolayısıyla Osmanlı sınırını ihlal etmesi halinde sert bir karş11ık vereceğini belirtmekle birlikte, şayet İran askeri Osmanlı sınırına bir zarar vermezse o zaman ne olabileceği hususu gündeme gelmiştir. Ayrıca Şikâk Ali Ağa, Osmanlı tarafına geçmeyi başarırsa bu sefer de İran tarafında kalan bu aşirete mensup kimselerin canları ve mallarının tehlikede olacağı gündeme getirilmiştir. Açıkçası çatışmanın olduğu yerin tartışmalı mahallerden bir yer olması dolayısıyla, meselenin ona göre belirlenip hareket edilmesinin önemine tekrar vurgu yapılmıştır. Şikâk Ali Ağa'nın Osmanlı tarafına ailesi ile birlikte geçmesi olasılı̆̆g durumunda da onları takip eden İran askerinin Osmanlı sınırını ihlal etmesinin söz konusu olabileceği ve buna mani olunması noktasında da Kotur havalisinde bulunan nizami asker komutanlarına durumun bildirilip ona göre hazırlıklı olmaları kararlaştırılmıştır. ${ }^{43}$

$\mathrm{Bu}$ arada Osmanlı'ya gelen istihbaratta, Şikâk Ali Ağa'yı saklandığı kaleden çıkarıp teslim almak üzere İran tarafından görevlendirilmiş olan üç yüz kadar askerin Coni kalesini kuşattığ 1 bilgisi gelmiştir. Yine İran askerinin tartışmalı yerler arasında bulunan Kotur taraflarında bulunduğu haberinden Osmanlı'nın duyduğu rahatsızlık açıkça ifade edilmiştir. Osmanlı

\footnotetext{
${ }^{39}$ Coni bir köy yerleşimi olup mevki olarak Urmi’ye bağlı olan Somay mahalli içerisinde bulunmaktadır. Mehmed Hurşid Paşa, a.g.e., s. 249.

${ }^{40}$ Burası, Van Eyaleti dâhilinde bulunan Hakkâri’ye bağlı bir yerleşim yeridir. Van merkezine on iki saat mesafededir. Cari'de bir kale de bulunmaktadır. BOA., H. H., D. No: 1314, G. No: 51255

${ }^{41}$ BOA., A. MKT.UM., D. No: 62, G. No: 44.

${ }^{42} \mathrm{Bu}$ konulara ilişkin bilgi için bkz. M. Rıza Nasırî, a.g.t., s. 36-58.

${ }^{43}$ BOA., A. MKT.UM., D. No: 62, G. No: 44.
} 
yönetimine göre tartışmalı yerlerde bulunan aşiretlerin, faraza İran topraklarına gidip fesatlıkta bulunmaları veya oralara zarar vermeleri durumu olsa bile, bu konunun halli noktasında iki devletin yetkili birimlerinin görüşüp ortak hareket etmesi gerektiği vurgusu yapılmıştır. Zira o zamana kadar hudut üzerinde bu gibi olumsuzlukların yaşandığına dair pek çok hadise örneğinden yola çıkılarak, bir tarafın tek başına harekete geçip öte taraf sınırlarına zarar vermesinin asla kabul edilebilecek bir durum olmadığının altı çizilmiştir. Bu çerçevede Osmanlı yönetimi, İran'ın bir komutan emrine öyle askerler tahsis edip yanına başıbozuk adamlar verip, o mevkilerde Osmanlı Devleti'nin sanki hiç bir hakkı yokmuşçasına harp edip, kale zapt etmesinin kabul edilebilecek bir husus olmadığını vurgulamıştır. Böyle uygunsuz davranışların iki taraf antlaşmalarına aykırı olduğu da belirtilmiştir. ${ }^{44}$

Osmanlı yönetimi, İran'ın bu rahatsız edici tavrının sebeb-i hikmetini öğrenmek, Şikâk Ali Ağa'nın iadesini temin etmek ve tartışmalı mahaller statüsünde olan yerlerde kesin hudut çizgisi belirleninceye kadar buralara müdahale olunmamasını sağlamak üzere harekete geçmiştir. $\mathrm{Bu}$ çerçevede de Hacegân-1 Divan-1 Hümâyûndan Hamdi Efendi'nin yanına Zabitân-1 Asker-i Nizâmîye'den bir yüz başı alarak İran askerinin bulunduğu yere gönderilmesi kararlaştırılmıştır. Ayrıca Çölemerik'te bulunan Osmanlı nizami askerinden de yarı tabur muntazam askerin Kotur tarafina gönderilmesi ihtiyaten uygun görülmüştür. ${ }^{45}$

Tüm bu hazırlıklara ve girişimlere rağmen Şikâk Ali Ağa sorunu, Osmanlı'nın istediği şekliyle sonuçlanmamıştır. 1853 senesine gelindiğinde Şikâk Ali Ağa meselesi gündemdeki yerini korumaya devam etmiştir. Bu süreçte Şikâk Ali Ağa'nın İran tarafindan ele geçirilip tevkif edilmesi söz konusu olmuştur. Gelişmelerden son derece rahatsız olan Osmanlı yönetimi, Şikâk Ali Ağa meselesi bağlamında aşiretlerin problemli halinin oluşturduğu gerginlikten duyduğu sıkıntıyı ortaya koymuştur. Osmanlı Devleti, o sıralar Süleymaniye havalisindeki aşiretlerin yağmacılık hallerini ve bundan devlet olarak duyduğu huzursuzluğu da dile getirmiştir. ${ }^{46}$

Şikâk Ali Ağa ile Herekî/Herkî aşiretinin ${ }^{47}$ Revândız taraflarında olmaları zannıyla ilgili, bu konuda tahkikat yapılmasının gerekliliğinden bahsedilmiştir. Görevlendirilen memur tarafından yapılan tahkikatın tam sonucu belli olmamakla birlikte, o havaliden alınan istihbarat bilgilerine göre, 1853 yılı itibariyle Şikâk aşiretinin iki bin beş yüz haneden fazla bir sayıya sahip, muteber bir aşiret olduğu belirtilmiştir. Şikâk Ali Ağa'nın, aşiretin büyüklerinden kabul edildiği, bunların Osmanlı tebaasından olduğunun altı çizilmiştir. Şikâk aşiretinin bir kısmının kış mevsiminde Revândız Sancağında, diğer kısmının ise Musul Mutasarrıflığı dâhilindeki Akra kazasında sakin oldukları ifade edilmiştir. Şikâk aşireti, bahar vaktinde İran tarafında yaylaklarında bulunarak gelirlerini bu suretle temin ettikleri vurgulanmıştır. ${ }^{48}$

Musul'un önceki idarecileri olan Mehmed ve Resul Paşalar zamanında Şikâk aşiretine Osmanlı'nın layıkıyla sahip çıkamadığı, bundan dolayı da bu aşirette İran tarafina meyilli bir durumun olduğu Osmanlı yönetimince itiraf edilen bir husus olmuştur. $\mathrm{Bu}$ arada bu aşiret

\footnotetext{
${ }^{44}$ BOA., A. MKT.UM., D. No: 62, G. No: 44.

${ }^{45}$ BOA., A. MKT.UM., D. No: 62, G. No: 44.

${ }^{46} \mathrm{Bu}$ konuya ilişkin orijinal metinde geçen ifadeler şu şekildedir: "Süleymaniye 'aşâ̂rinin bazı nehb-ü emvâl misüllü harekât-ı nâ-marziyyeye cesaretleri vuku 'uyla...” BOA., İ. MVL., G. No: 11798, B. No: I. İrade Meclis-i Vâlâ, (İ. MVL), G. No: 11798, kayıtlı bu arşiv vesikası içerisinde konuyla alakalı pek çok belge bulunmaktadır. Ancak belgelerin bazılarının üzerinde herhangi bir numara bulunmamaktadır. Bununla birlikte bazılarına sonradan verildiği anlaşılan roma rakamlı numaralar vardır. Bu bakımdan bu arşiv vesikasına atıf yaparken belgenin tarihine, roma rakamına veya üst kısmında kimden-kime gittiğine dair bilgilerden hareket edilmiştir.

${ }^{47}$ Herekî aşiretini, Sykes, Herki olarak belirtmektedir ve onun verdiği bilgilere göre de Herkî aşireti üç bin aileden oluşan büyük bir göçebe aşirettir. Bu aşiretin bir kısmı Erzurum çevresinde bulunurken diğer kısmı Van dolaylarındadır. Büyük bir bölümü ise Musul'dadır. M. Sykes, a.g. m., s. 458.

${ }^{48} \mathrm{Bu}$ hususa ilişkin arşiv belgesindeki bilgiler şu şekildedir: “ mezbûr Şikâk aşireti denilen iki bin beş yüz haneden mütecâviz mu'teber bir aşiretin ve büyükleri merkûm Şikâk Ali Ağa evladın bunlar teba'-ı Devlet_ $i$ Aliyyeden bulundukları halde mevsim-i şitâda bir firkası Revândız Sancă̆ı'nda ve diğer firkası dahi Musul Mutasarrıflı̆gna mülhâk Akra kazasında sâkin ve bahar vaktinde yaylaklarında arâm ve temekkün ile mal-ı mirîlerini edâ idegelmekde iken..." BOA., I. MVL., G. No: 11798, B. No: I.
} 


\section{F.Ü. Sosyal Bilimler Dergisi 2015-25/2}

mensuplarının Osmanlı-İran sınırı boylarında tartışmalı yerlerde bulunmaları ve o sıralar Şikâk Ali Ağa'nın çıkardığı sorunlardan dolayı İran memurları tarafından tevkif edilerek Tahran'a götürülmesi söz konusu olmuştur. Sonrasında da Şikâk Ali Ağa tutuklanarak Tahran'da Faraşbaş1 (?) isimli hapishaneye konulmuştur. Bu arada Aşiret liderliğinden de azledilen Şikâk Ali Ağa'nın yerine kendi akrabalarından olan Mirza Ağa tayin edilmiştir. ${ }^{49}$

Bu meyanda bir yolunu bulan Şikâk Ali Ağa hapisten firar ederek, önce aşireti içerisine oradan da Musul'a bağlı aşiretlerden Şemzin/Şemzinan aşiretinin yanına gelerek burada bulunan Şeyh Taha Efendi tekkesine sığınmıştır. Akra kazasına bağlı olan Herekî aşiretinin yaylakları bu tekkeye civar olup, o sıralar aşiretin de yaylakta bulunması dolayısıyla Herekî aşiretinin reisi konumunda bulunan Hacı Beğ ile Şikâk Ali Ağa arasında görüşmeler olmuştur. Bu görüşmeler sonucunda Şikâk Ali Ağa, kendisinin İran tarafından affedilmesi hususunda, Hac1 Beğ'den aracı olmasını istemiştir. Hacı Beğ, Rumiye Hâkimi'ne mevcut durumu ifade eden birkaç mühürlü mektup yazmıştır. Rumiye Hâkimi bu mektupları önce Tebriz'e göndermiş sonrasında da mektuplar Tahran'a iletilmiştir. Şikâk Ali Ağa, İran ile olan meselesinin daha da büyümesini istemediği için ailesini ve yakın akrabalarını yanına alarak Hakkâri dâhilinde bulunan Bestke köyüne gidip buraya yerleşmiştir. O sıralar Şikâk aşiretinin bir kısmının Osmanlı ile İran arasında ihtilaflı yerlerden olan Gürtergür nahiyesi taraflarında sakin bulundukları bilgisi verilmiştir. İran, gerek Şikâk Ali Ağa'nın kendisinden ve gerekse aşiretinden duyduğu rahatsızlık ile bunların çıkardıkları problemler dolayısıyla şikâyetini Osmanlı yönetimine iletmiştir. Osmanlı yönetimi meselenin tam bir netlik kazanmamış olmasından bahisle de mevzunun iyice tahkik edilmesini uygun bulmuştur. ${ }^{50}$

\section{Menkûr/Menkûrî Aşireti Meselesinin İki Devlet Arasındaki Gerginlik Konusu}

Şikâk Ali Ağa meselesinin Osmanlı açısından doğurduğu rahatsız verici durum etkisini sürdürürken başka bir aşirete dair yeni bir mevzu ortaya çıkmıştır. Buna göre Osmanlı Devleti tebaasından olup İran tarafında bulunan Menkûr Aşireti Reisi Babür Ağa'nın tekrar Osmanlı'ya celbi konusunda Osmanlı yönetiminin girişimleri olmuştur. Bu kapsamda da Osmanlı-İran hududunun belirlenmesinde Osmanlı tarafindan görevlendirilmiş olan Derviş Paşa'ya ve Bağdat Valisi Namık Paşa'ya bu hususla ilgili yazılar yazılmıştır. Aynı zamanda bahsi geçen Menkûr ${ }^{51}$ aşiretinin Süleymaniye havalisi aşiretlerinden olması dolayısıyla da Süleymaniye Kaymakamı Münib Paşa'ya durum bildirilmiştir. ${ }^{52}$

Babür Ağa meselesinin ortaya çıktığı tarihte kendisinin Soğukbulak’a (Savucbulak) ${ }^{53}$ yakın olan, ancak o sıralar Osmanlı-İran sınır tespiti konusunda iki taraf içinde tartışmalı yerler mesabesinde olan (münâza'un-fih mahaller) bir mevkide bulunması işin karışık bir hal almasına sebebiyet vermiştir. O sıralar Soğukbulak Hâkimi olan Kerim Han'ın, Osmanlı'nın taleplerine karşılık Babür Ağa'yı teslim etmemesi söz konusu olmuştur. Hatta Kerim Han, Babür Ağa'nın İran tebaasından olduğunu iddia etmiştir. ${ }^{54}$

Gelişmelerden rahatsız olan Osmanlı yönetimi, durumu İran'daki Osmanlı sefirine iletmiştir. Bu konuyla alakalı olarak İranlı yetkililer ile yapılan görüşmelerde Osmanlı Devleti'nin üzerinde durduğu hususlar şunlar olmuştur. Babür Ağa'nın mensubu olduğu Menkûrî taifesi eskiden beri Süleymaniye'ye bağlı aşiretlerden biri olup, senelik bin kırat vergi vermektedir. Yine bu aşiretin Süleymaniye havalisi içerisinde Dikahköy havalisinde bulundukları hususu, Süleymaniye Kaymakamı Münib Paşa tarafından bildirilmiştir. Osmanlı yönetimince İran'a yapılan bu izahlara rağmen Babür Ağa'nın Osmanlı'ya iadesi hususu bir türlü gerçekleşmemiştir. Hatta Soğukbulak'da

\footnotetext{
${ }^{49}$ BOA., I. MVL., G. No: 11798 , B. No: I.

${ }^{50}$ BOA.,I. $M V L$., G. No: 11798 , B. No: I.

${ }^{51}$ Arşiv belgesinde sürekli olarak Menkûr/Menkûri aşireti ismi ile anılan bu aşiretin ismine M. Hurşid Paşa'nın Seyâhatnâmesi'nde rastlanılamamıştır. M. Hurşid Paşa, Süleymaniye aşiretlerine dair bilgi verirken buradaki aşiretlerden Mendümî taifesinden bahsetmektedir. M. Hurşid Paşa, a.g.e., s. 183.

${ }^{52}$ BOA., I. MVL., G. No: 11798. Belgenin tarihi 21 Camaziyelevvel 1269/ 2 Mart 1853.

${ }^{53} \mathrm{Bu}$ yerin diğer bir ismi de Savucbulak'dır. Mehmed Hurşid Paşa, a.g.e., s. 184.

${ }^{54}$ BOA., I. MVL., G. No: 11798.
} 
konsolos vekili olarak görev yapmış olan Kasım Ağa'nın, Revândız Kaymakamı Ragıp Paşa ile birlikte bu konuya ilişkin İran yönetimi nezdindeki girişimlerinden de bir sonuç çıkmamıştır. ${ }^{55}$

Durum Osmanlı açısından sıkıntılı bir hal alırken, İran yönetimi, Babür Ağa'yı Tahran'a çağırmıştır. Babür Ağa'nın Tahran'da bulunduğu süre içerisinde gerek İran Şah'ından ve gerekse İran üst yönetiminden bayağı bir iltifat görmesi söz konusu olmuştur. İran yönetimi, Babür Ağa'ya pek çok hediyeler ve hilatler vermesinin yanında, ayrıca kendisini belli bir miktar aylığa da bağlamıştır. Sonrasında da Babür Ağa'yı kendi bölgesine göndermiştir. Osmanlı yönetimi, İran'ın Babür Ağa mevzusunda böyle bir tavır takınmasından duyduğu memnuniyetsizliği, İran'ın öteden beri yönetim mizacında var olan olumsuz sabıkasına bağlamıştır. ${ }^{56}$

Babür Ağa meselesi özelinde Osmanlı yönetimi, İran ile yaşanan aşiretler sorununun değerlendirmesini şöyle yapmıştır. İran, o zamanki sınırlar meselesinin oluşturduğu hassas durumu göz önünde tutarak ve esasta Osmanlı'ya bağlı olan bazı aşiretleri aldatma suretiyle kendi yanına çekmek için çeşitli yollara başvurmuştur. İran, bu şekilde aşiretleri kendi yanına meylettirerek o sıralar iki devlet arasında çözülmemiş olan tahdid-i hudud (sınırların tespiti) meselesinde üstünlük kazanmaya çalışmıştır. Bilhassa bazı aşiretleri kendisindenmiş gibi göstermek için de "enva-yı desais" yoluna giden İran yönetiminin bu tavrının, komşuluk ilişkilerine yakışmadığ 1 belirtilmiştir. Nitekim Osmanlı yönetimi bu konuyu İran'daki sefirine; "İranlunun bu vecihle iğfâl-ı 'aşâ̂r hakkında desais-i hafìyyelerine meydan verilmeyeceği" hususunu belirten bir yazı gönderip, bu konularda diplomatik açıdan daha dikkatli olunması gerektiği ve İran yönetimine gerekli uyarıların yapılması istenmiştir. ${ }^{57}$

Babür Ağa meselesini yakından takip eden Osmanlı yönetimi, bu hususta o sıralar Tebriz'de bulunan Soğukbulak Konsolos Vekili Kasım Efendi'nin, Revândız Kaymakamı Ragıb Paşa'ya gönderdiği yazıda -24 Şevval 1269 / 31 Temmuz 1853 tarihi itibariyle- Babür Ağa'nın Tahran'dan, Soğukbulak'a geldiği bilgisini vermiştir. ${ }^{58}$

Bu arada Tahran'da bulunan Osmanlı Sefiri, daha Babür Ağa Tahran'da iken konağında bir davet vermiş ve bu davete Babür Ağa'yı da çağırmıştır. Ortamın rahatlığı münasebetiyle de yapılan konuşmalarda Babür Ağa, İran yönetiminin kendisine olan ilgisini bütün açıklığıyla anlatmıştır. Bu anlatımlara göre de İran Şah'1, Babür Ağa'yı huzuruna kabul ettikten ve kendisine iltifatta bulunduktan sonra hediye olarak; tüfek, güzel bir zırh, zırh kolçağı, zırh külahı, yüz tümen para, üç yüz tümen mevacib (maaş) ve bir güzel şal vermiştir. Babür Ağa, İran Sadrazamı ve Seraskerinin de kendisini kabul edip, çeşitli hediyeler verdiğini belirtmiştir. Bu hediyeler içerisinde; tüfek, şal, hilat, zırh, hatta altın kabzalı bir kılıç yer almakla birlikte, Babür Ağa'nın mensuplarından Mekrî ahalisinden olan dört kişiye de maaş tahsis edilmiştir. Yine kendisiyle beraber giden Seyyid Hidayetullah'a yüz altmış tümen mevâcib ve hediyeler verilmiş, bu zata Şah tarafından iltifat gösterilmiştir. Ayrıca Babür Ağa'nın oğluna da benzer şekilde İran yönetimi tarafından hediyeler verilmiş ve iltifat edilmiştir. ${ }^{59}$

Babür Ağa meselesindeki İran'ın tutumundan oldukça rahatsız olan Osmanlı yönetimi, 1852 senesinde Süleymaniyeli Azîz Bey'in cesaret ettiği küstahlık hengâmında Osmanlı’ya açtığı zarar ziyan ortadayken, bu meselede de İran'ın uygun olmayan tavrını gündeme getirmiştir. ${ }^{60}$ Açıkçası İran'ın Osmanlı içindeki aşiretler ve bunların reislerine yönelik kendi yanına çekme politikasının yansımaları sıkıntılı bir hal almaya başlamıştır.

\footnotetext{
${ }^{55}$ BOA., I. MVL., G. No: 11798.

${ }^{56}$ BOA., I. MVL., G. No: 11798.

${ }^{57}$ BOA., I. MVL., G. No: 11798.

${ }^{58}$ BOA., I. MVL., G. No: 11798. Dosyası içerisinde 28 Şevval 1269 / 4 Ağustos 1853 tarihli, Soğukbulak'da bulunan Tebriz Şehbender Vekili Kasım Efendi'nin, Revândız Kaymakamı Ragıb Paşa'ya olan varakası sureti olarak kayıtlıdır.

${ }^{59}$ BOA., I. MVL., G. No: 11798 .

${ }^{60}$ BOA., I. MVL., G. No: 11798.
} 


\section{F. ̈. Sosyal Bilimler Dergisi 2015-25/2}

Babür Ağa meselenin gelişmelerine baktığımızda da, Osmanlı Devleti, Ekim 1853 tarihi itibariyle bu mevzuyu yakından takip ederek, bahsi geçen Babür Ağa'nın Tahran'a götürülmesi ve burada başta İran Şah'1 olmak üzere İran üst yönetiminin ona karşı sergilediği taltif edici tavrı analiz etmiştir. ${ }^{61} \mathrm{Bu}$ analize göre, İran bu tip davranışlar sergileyerek belirli bir havalideki aşiretleri ve onların başındaki reisleri/ağaları kendi yanına çekmek istemiştir. Gelişmeleri Osmanlı hariciyesinin yakından takip ettiği ve duruma göre gerekli girişimlerde bulunmaya hazır olduğu da vurgulanmıştır. O sıralar Soğukbulak'da ikamet etmekte olan Tebriz Konsolos Vekili Kasım Efendi tarafından Köy-Sancak Müdürü Selim Ağa'ya gönderilen yazıdan da anlaşılacağı üzere İran içindeki durum yakından takip edilmiştir. Buna göre İran Şahı'nın Sultaniye ${ }^{62}$ yaylağından ayrılıp Tahran'a geldiği bilgisi verilmiştir. İran'ın o sıralar aşiretler konusunda bazı girişimlerinin olacağı haberi alınmakla birlikte, İran'ın bu durumu bir nevi devlet politikası haline getirdiğinin altı çizilmiştir. $^{63}$

Bu meyanda Süleymaniye’ye bağlı olan Köy-Sancak aşiretlerinden olan Sin/Sün Aşireti Ağas1 Hızır Ağa'nın bir iki kez İran üst yönetimi tarafından çağrılarak, kendisine senelik 200 tümenlik bir maaş tahsis edilmesi söz konusu olmuştur. Ayrıca Revândız Sancağı'na bağlı Balık nahiyesinden Mîr Azîz'in İran tarafına firar etmesiyle birlikte kendisine İran memurları tarafından büyük iltifatlar yapılarak, Tahran'a götürülmek istenmiştir. Bu bilgiler neticesinde Osmanlı yönetimi, İran'ın bu havalideki bazı aşiret liderlerini celb ve iğfale çalışmasından duyduğu memnuniyetsizliği açıkça belli etmiştir. İran'ın bu tavrının Osmanlı iç işlerine müdahale, sınır boylarında asayişin bozulması ve aşiretlere ait düzenin zedelenmesi anlamına geleceği belirtilmiştir. ${ }^{64}$

Bahsi geçen Mîr Azîz'in Osmanlı tebaasından olduğu ve çıkardığı hadiselere bağlı olarak hakkında yürütülen takibat neticesinde, Sivas'a sürgün edilmesine karar verildiği, onun da bundan dolayı İran tarafina firar ettiği bilgisi verilmiştir. Hatta Mîr Azîz'in teslim olmasının sağlanması bağlamında tedbir ve teminat için oğlu Ahmed'in, gözaltında tutulması ve bu meyanda babasının teslimi söz konusu iken, birden Mîr Azîz'in bazı evhamlar ile firar edip Osmanl1-İ̈ran sinırlarında dolaşması ve İran'ın ona yönelik yakın tutumundan Osmanlı'nın rahatsızlığı dile getirilmiştir. Bu konuda harekete geçmesi için Tebriz Konsolosu Ali Rasim Efendi uyarılmıştır. Ali Rasim Efendi, Mîr Azîz'in teslimi hususunda İran memurları ile yaptığı görüşmelerden sonra, bahsi geçen kişinin teslim edileceğine dair bir haberi İstanbul'a iletmiştir. Ancak İran'in bu sözünü de yerine getirmediği geçen zaman içinde anlaşılmıştır. Osmanlı yönetimi, İran'ın bu konulardaki desiselerini bildiğinden Mîr Azîz'in, Babür Ağa örneğinde olduğu gibi Tahran'a götürülüp burada taltiflerde bulunulup İran tarafina çekilmesinden endişe etmiştir. Bunu engelleme adına da Tahran'daki Osmanlı Sefiri Ahmed Vefik Efendi'nin bilgilendirilmesi uygun görülmüştür. ${ }^{65}$

$\mathrm{Bu}$ gelişmeler bağlamında Süleymaniye tarafı aşiretlerine yönelik Osmanlı yönetiminin ilginç ve dikkat çekici tespitleri olmuştur. Buna göre; bu havali aşiretlerinin uyanık Kürtler kabilinden olduğu ve bunların ekserinin her sene yaylak için İran'a gittikleri belirtildikten sonra, o sıralar Osmanlı ile İran arasında sınır tespiti meselesinin gündemde olması ve bu vesileyle iki devletin de aşiretleri alttan alma mecburiyetinde bulundukları düşüncesinin aşiret yöneticilerindeki temel alg1 olduğu vurgulanmıştır. ${ }^{66}$

\footnotetext{
${ }^{61}$ BOA., I. MVL., G. No: 11798, B. No: I. Belgenin tarihi, 19 Muharrem 1270 / 22 Ekim 1853'dür.

${ }^{62}$ Sultaniye, İran'ın, kuzeyinde bulunan Zencan eyaletinde bir yerdir. Konumu itibariyle bir nevi yaylak özelliği taşıması ve yaz aylarının daha serin olması dolayısıyla İran şahlarının yaz mevsimini geçirdikleri önemli bir mevkidir.

${ }^{63}$ BOA., I. $M V L$., G. No: 11798 , B. No: I.

${ }^{64} \mathrm{Bu}$ hususa ilişkin arşiv belgesinde geçen ifadeler şu şekildedir: "Iranlu tarafindan bunlar ve emsâli bazı 'aşâ̂r rüesâsının celb ve iğfallerine çalışılması rivayâtı saye-i şevket-vâye-i hazret-i şâhânede der-dest olan asayiş ve zabıta-i 'aşâ̂r ve mevki yenin ihlalini istilzâm ideceği melhûzatdan ..." BOA., İ. MVL., G. No: 11798, B. No: I.

${ }^{65}$ BOA., I. MVL., G. No: 11798 , B. No: I.

${ }^{66}$ Metnin orijinalinde durum şu ifadeler ile geçmektedir: " bu havâli 'aşâ̂ri ekrâd-ı bî-dâr kâbilinden olub ekserisi bermu 'tad îfâ-yı yaylakıye zımnında beher sene cânîb-i İan'a gider takımından olmalarıla...” Bu ifadelerdeki bî-dâr kelimesinin lûgatlardaki kelime anlamı iki tanedir. Bunlar; uyanık, gözü açık ve yersiz, yurtsuzdur. Belgedeki ifadelerin bütünü göz önünde tutulduğunda daha çok uyanık anlamında kullanıldığı anlaşılmaktadır. BOA., $\dot{I}$. MVL., G. No: 11798 , B. No: I.
} 
$\mathrm{Bu}$ çerçevede Osmanlı yönetimi bu aşiretlere; "muamele-i nermâne ile hoşça tutulub öte tarafa amele-i nikâha sevk ve rağbetlerine sebebiyet verilmemesi hakkında nazar-ı dikkat" edilmesinin önemini belirtmiştir. ${ }^{67}$ Osmanlı'nın ifade ettiği bu hususlara dikkatli bir şekilde baktığımızda, iki devlet arasında var olan hudut anlaşmazlıkları çerçevesinde aşiretlerin önemli birimler haline geldiği ve hangi tarafın hangi aşireti kendi yanına çekerse bu kapsamda üstünlük sağlayacağı belli olmuştur. Hal böyle iken, bazı aşiretlerin o sıralar Osmanlı için olumsuz tutumları olmuş ise de onların hoşça tutulması ve İran tarafına geçip, oranın tebaası olmasının engellenmesi hususu, devletin önemli bir politikası haline gelmiştir.

İşte bu hassas vaziyetin bilincinde olan aşiretlerin, tutumlarının yakından izlenmesi konusunda, Süleymaniye ve Revândız sancaklarıyla, Köy-Sancak kazası yöneticilerinin (Münib Paşa, Ragıb Paşa ve Salih Ağa) çok dikkatli olmaları istenmiştir. Özellikle İran'ın bu havalideki aşiretleri bir şekilde etkileyip kendi yanına çekme hadisesinin önüne geçilmesinin önemi vurgulanmıştır. Ancak mevzunun en hassas noktasını ise, bu aşiretlerin mutat olduğu üzere yaylak için İran'a gittikleri zaman İran'ın bunlara ne şekilde muamele ettiğinin anlaşılması oluşturmuştur. Ayrıca bu aşiretlerin İran tarafina yönelik uygunsuz hareketlerinin engellenmesinin öneminden de bahsedilmiştir. Zira yukarıda bahsi geçen yerlerin Osmanlı-İran sınır bölgesi üzerinde olması ve o sıralar devam eden hudut tespiti bağlamında ortaya çıkan nazik durum çerçevesinde meselenin hassasiyetine tekrar dikkat çekilmiştir. ${ }^{68}$

\section{Zilân Aşireti ve Bu Aşiretin Reisi Kasım Ağa İle İlgili İran'ın Şikâyeti}

Erzurum'da ikamet eden İran Şehbenderi aşiretler konusuna ilişkin olarak İran'ın bazı şikâyetlerini dile getirmiştir. Bu çerçevede özellikle 1850 yılı başlarında Zilânlı Kasım Ağa konusunda İran'ın rahatsızlık duyduğu ifade edilmiştir. Hatta İran, Osmanlı Devleti aşiretlerinden olup bir süre önce İran tarafına firar etmek isteyen Hasenanlu taifesini kabul etmediğini ve sınırından içeriye girmesine izin vermediğini belirtmiştir. Buna bağlı olarak da Zilânlı aşireti meselesinde Osmanlı'nın aynı hassasiyeti göstermesini isteyen İran, Zilân aşiretinin kendi aşiretlerinden biri olduğunu da iddia etmiştir. Zilânlı Kasım Ağa'nın tevkif edilmesini de İran, kendi iç meselesi olarak görmüş, Osmanlı'nın buna müdahale etmemesini istemiştir. Osmanlı yönetimi ise, İran'ın kendi aşiretinden olduğunu iddia ettiği Zilânlı aşireti ve bu aşiretin reisi konumunda bulunan Kasım Ağa'nın İran tarafından tevkif edilmesinden duyduğu rahatsızlığı belirtilmiştir. Nitekim Zilânlı aşiretinin Osmanlı aşiretlerinden biri olduğu vurgusu yapılmıştır. İran elinde bulunan Kasım Ağa'nın iadesi hususunda Osmanlı'nın Azerbaycan'daki şehbenderine bilgi verildiği ve gereğinin yapılmasının beklendiği de ifade edilmiştir. ${ }^{69}$

Yine bahsi geçen Hasenânlu taifesinin öteden beri Osmanlı Devleti'ne bağlı olan, Muş Sancağında sakin yerli aşiretlerden iken bir müddet önce aşiretin Ağası konumunda olan Ridvan Ağa'nın bazı gerekçelerle İran tarafına firar ettiği belirtilmiştir. Onun bu firarı meselesi Anadolu Ordusu Müşiri vasıtasıyla Osmanlı yönetimine bildirilmesi üzerine, bu konunun halli için memurlar görevlendirilmiş ve yapılan girişimler sonrasında Rıdvan Ağa iade edilmiştir. Bu çerçevede Osmanlı yönetimi Zilân aşiretinin de bütünüyle Osmanlı tebaasından olduğu belli iken İran'ın bu meseleyi bile tartışmalı konular haline getirmesinin anlaşılmaz bir durum olduğunu vurgulamıştır. Ayrıca bunlar İran'ın iddiaları doğrultusunda tartışmalı aşiretler kapsamı içerisinde olsalar bile, 1847 tarihli Erzurum Antlaşmasının sekizinci maddesi hükmü uyarınca, kendi rey ve iradeleri ile istedikleri tarafa geçme haklarının bulunduğuna dikkat çekilmiştir. Bu bağlamda gerek Ridvan Ağa meselesinde ve gerekse Rıdvan Ağa ile beraber hanesiyle İran tarafina geçmiş olan Haydaranlu Mîr aşiretinden Haydar Ağa'nın İran tarafından tevkif ve taltif olunmasının kabul edilebilir bir durum olmadığı belirtilmiştir. Bu çerçevede bunların iadesi hususunda Osmanlı'nın girişimlerinin olacağı da söylenmiştir. ${ }^{70}$

\footnotetext{
${ }^{67}$ BOA., I. MVL., G. No: 11798 , B. No: I.

${ }^{68}$ BOA., I. MVL., G. No: 11798 , B. No: I.

${ }^{69}$ BOA., HR. MKT.UM., D. No: 29, G. No: 63. (5 Rebiulevvel 1266 / 19 Ocak 1850)

${ }^{70}$ BOA., HR. MKT.UM., D. No: 29, G. No: 63.
} 


\section{F. Ü. Sosyal Bilimler Dergisi 2015-25/2}

\section{Kelâlî Aşireti’nin Çıkardığı Sorunlar}

Kelâlî Aşireti hakkında Mehmed Hurşid Paşa'nın verdiği bilgilere bakacak olursak; 1850'li yıllar itibariyle şunlar göze çarpmaktadır. $\mathrm{Bu}$ aşiret Şehrizor Eyaleti dâhilinde bulunan Süleymaniye Sancağına bağlı olan ve İlgavâre diye adlandırılan on iki aşiretten biridir. Kelâlî aşiretinin o zamanki hane sayısı beş yüzdür. Aşiret yıllık olarak on beş bin kuruş vergi vermektedir. Mezhebi Şafi ‘̂̂' dir. Bahar aylarında İran topraklarından olan Savucbulak'a (Soğukbulak) giderler ve burada yaylarlar. Güz mevsiminde Süleymaniye taraflarına gelirler ve Kerkük'e kadarki geniş alan içerisindeki havalide kışlarlar. İran memleketlerine gittiklerinde vergi vermemekte ve ora ahalisine zulmetmede Câflarla ${ }^{71}$ aynı karakterdedirler. Kelâlî aşireti dâhil olmak üzere Süleymaniye'deki diğer aşiretler yaz mevsiminde yaylak için İran tarafina geçmeğe ihtiyaçları var ise de, Osmanlı tarafında olan kışlaklarına ihtiyaçları daha fazladır. Zira yaz mevsiminde İran tarafına geçmek zorunda olmayıp, Osmanlı topraklarında kalarak hayvanlarını burada beslemeleri mümkündür. Hâlbuki kış mevsiminde İran tarafında kışlayacakları münasip yerlerin olmadığı da vakıadır. $^{72}$

Yukarıda kısaca ifade ettiğimiz bu temel özelliklere sahip olan Kelâlî Aşireti ile ilgili 1853 senesinde ortaya çıkan ve İran tarafından dile getirilen şikâyetler söz konusu olmuştur. Buna göre bu aşiret yaylak için 1853 senesi yaz mevsiminde İran'a gittiğinde bazı köylere zarar vererek, burada yaşayan ahalinin mal ve eşyalarını yağmalamışlardır. Bununla da yetinmeyip, İran tarafında bazı kimseleri öldürüp, rezilliklerini arttırmışlardır. Ayrıca Hakkâri havalisindeki bazı Kürtlerin de bazı yaramazlık hallerinin olduğu ve İran'ı muzdarip eden davranışlarının bulunduğu belirtilmiştir. Buna bağlı olarak Şikâk Ali Ağa'nın da Soğukbulak (Savucbulak) havalisinde bulunan bazı Kürtleri başına toplayıp İran'a rahatsızlık verdiği hususu İran tarafından Osmanlı'ya bildirilip şikâyet mevzusu olmuştur. ${ }^{73}$

Osmanlı yönetimi, bu şikâyetleri dikkate alıp, İran ile Osmanlı arasındaki münasebetlere ilişkin diplomatik bazı ifadeler zikrettikten sonra, bahsi geçen aşiretlerin yaptıkları uygunsuz hareketlerin kabul edilebilir bir durum olmadığını belirtmiştir. Bu çerçevede devlet olarak lazım gelen tedbirlerin acilen alınacağı da ifade edilmiştir. Bilhassa İran tarafından yağmalanan eşyaların iadesinin sağlanacağı, iki taraf hudut ve ahalisinin her türlü baskı ve tecavüzden uzak tutulmasına itina gösterileceğine vurgu yapılmıştır. Osmanlı yönetimi, bahsi geçen konular çerçevesinde üzerine düşen her türlü tedbiri alma noktasında sınır bölgesindeki idarecileri uyardığını da belirtmiştir. Özellikle bu havali aşiretlerinin yaptı̆g 1 bu tip olumsuz davranışların süreklilik göstermesinden muzdarip olduğu belli olan Osmanlı Devleti, bu aşiretlerin akılsız bir takım ekrâd-l bî-idrâkdan oluştuğunu belirterek öfkesini göstermiştir. Bu aşiretlerin Osmanlı toprağında iken, İran tarafına saldırma ve yağma faaliyetlerinde bulunmalarının önüne geçilmesinin zaruret olduğu da ifade edilen hususlardan olmuştur. Ancak geleneksel bir vakı olan ve bu havalideki aşiretlerin büyük çoğunluğunun göçebe hallerinin, yaylak ve kışlak gidiş gelişlerinin bir çeşit vazgeçilmez hal olduğunu da bilen Osmanlı yönetimi, buna bağlı olarak yüzyıllardır süregelen bu tip olumsuz hadiselerin öyle çok da kolay çözümlenemeyeceğini vurgulamıştır. ${ }^{74}$

Nitekim Süleymaniye Aşiretlerinden olup, Osmanl1-İran sınır bölgesinde bulunan Kelâlî aşireti ile İsmaîl Azîzî taifesinin 1853 senesinde İran'da yaylak için bulundukları sırada İran'a ait aşiretlerin bazılarının mal ve eşyalarını yağmalayıp gasp etmeleri söz konusu olmuştur. Bu hususun gerek İran tarafindan Osmanlı'ya bildirilmesi ve gerekse Osmanlı Devleti'nin yaptığ tahkikat sonucu ortaya çıkması Osmanlı açısından rahatsız edici bir durumu oluşturmuştur. Osmanlı

\footnotetext{
${ }^{71} \mathrm{Bu}$ havalinin en büyük aşiretlerinden biridir.

${ }^{72}$ Mehmed Hurşid Paşa, a.g.e., s. 183-184.

${ }^{73}$ Konuya ilişkin arşiv belgesinde geçen ifadeler şu şekildedir: " Şehrizor Eyaleti dâhilinde bulunan 'aşâîrden Kelâlî 'aşiretinin yaylak münasebetiyle İran'a duhûllerinde bazı kurayı urarak bir takım emvâl ve eşya nehb-u garet ve itlâf-ı nüfus ve sair güne fezâhata cesaret ve Hakkari kürdleri dahi pek çok yaramazlı̆̆a mübâderet eylediklerine ve Tahran habishanesinden firar itmiş olan Şikâk Ali nam şahıs Savucbulak havalisinde bulunan kürdleri başına toplayub öte tarafa itale-i dest-i hasaret itmekde olduklarına dair..” BOA., I. MVL., G. No: 11798, B. No: II.

${ }^{74}$ BOA., I. MVL., G. No: 11798, B. No: II.
} 
yönetimi Süleymaniye Kaymakamı Münib Paşa'yı uyararak gerekli tedbirler almasını istemiştir. Ayrıca Münib Paşa tarafından bu konuya ilişkin araştırma ve inceleme yapmak üzere memurlar tayin edilmesi de kararlaştırılmışıır. ${ }^{75}$

$\mathrm{Bu}$ çerçevede İran aşiretlerine ait olup yağmalanan mal ve eşyaların bahsi geçen Osmanlı aşiretlerinden geri alınması ve bunların İran memurlarına teslimi üzerinde durulmuştur. Ayrıca İran memurlarına teslim edilecek malların niteliği ve miktarına ilişkin yazılı bir senet alınması istenmiştir. Bu süreçte üzerine en çok görev düşen kişi de Süleymaniye Kaymakamı Münib Paşa olmuştur. Gasp edilen İran aşiretlerine ait mal ve eşyaların geri alınması, bunların İran memurlarına teslim edilip tesellüm belgesi tanzim edilmesi ve bu belgelerin bir suretini gerek Tahran'a gerekse de İstanbul'a gönderilmesi hususunda kendisi görevlendirilmiştir. Ayrıca mevzunun Osmanlı hariciyesi tarafindan da takip edilmesinin gerekliliği üzerinde durularak; "emvâl-i menhûbeden nesne kalmuş ise tamamen ahz ve istirdâdıyla 'aşâ̂r-i merkûmenin kat'en tahatti ve ta 'addiye yol verilmemesinin "önemine dikkat çekilmiştir. ${ }^{76}$

Ayrıca Şikâk Ali Ağa'nın nasıl bir kişi olduğuna dair Osmanlı yönetiminde bir bilgi bulunmadığı, bundan dolayı da onun hakkında mahallinde kapsamlı bir araştırma yapılması istenmiştir. Ayrıca Şikâk Ali Ağa'nın Osmanlı sınırları içerisinde bulunması halinde de yakalanması hususu Münib Paşa'ya havale edilmiştir. Yine Revândız Sancağı aşiretlerinden biri olan Herekî/Herkî aşiretinin önceden bazı olumsuz hallerinin bulunduğu ve bundan böyle, "livâ-i mezkûr 'aşâîinden o makule harekât-ı tecavüziye ictisâr idenler olduğu takdirde men' ve ref 'leriyle" bu tip hadiselerin önün geçilmesinin gerekliliği belirtilmiştir. Özellikle o sıralarda Şikâk Ali Ağa ile Herekî/Herkî aşireti ağası Hacı Ağa arasında var olan ittifak göz önünde bulundurulduğunda, Şikâk Ali Ağa'nın İran memurlarına tesliminin de söz konusu olduğuna vurgu yapılmıştır. Bu çerçevede Revândız Kaymakamı Ragıb Paşa'nın gelişmeleri yakından takip edip, Osmanlı yönetimine bildirmesi istenmiştir. ${ }^{77}$

Esasında Osmanlı yönetiminin o zamanki en önemli sıkıntılarından biri, merkezden uzak bölgelerde meydana gelen hadiselerin zamanında İstanbul'a bildirilmemesinden kaynaklandığı anlaşılmaktadır. Bu durumdan yakınan Osmanlı idaresi, ancak bir hadise vuku bulduktan sonra veya İran Devleti'nden bir şikâyet gelmesi üzerine mevzulardan haberdar olmasından duyduğu memnuniyetsizliği belli etmektedir. Bilhassa o sıralar Osmanl1-İran sınır meseleleri ve tartışma konuları göz önünde bulundurulduğunda, mahallindeki vakaların günü gününe tespiti, olup bitenlerin takibi ve en azından bir olumsuz hadise olmadan önce meselenin önüne geçilmesinin önemi de kendini belli etmektedir. Yukarıda da ifade edildiği üzere pek çok soruna sebebiyet veren Şikâk Ali Ağa ile ilgili Osmanlı merkezi idaresinde hiçbir bilginin bulunmaması, devletin istihbarat akışındaki zaafiyetini, sınır bölgelerindeki durumlara ilişkin sıkıntılı halini ve buralardaki idarecilerin yetersizliğini belli eden hususlar olarak karşımıza çıkmaktadır.

Osmanlı idaresinin Süleymaniye havalisindeki yerel idarecileri uyarması sonrasında buradan gelen bilgiler doğrultusunda, sadece Kelâlî Aşireti mevzusu ve İsmail Azîzi taifesinin karıştı̆̆ olaylar dışında o an için başka bir hadisenin vuku bulmadığı ve diğer aşiretlerden İran tarafina yönelik bir saldırının bulunmadığı bilgisi gelmiştir. Özellikle Münib Paşa'nın olup bitenler bağlamında daha da dikkatli hareket ettiği, gönderdiği raporlardan anlaşılmıştır. ${ }^{78}$

Zira Şehrizor Eyaleti dâhilinde bulunup da İran tarafına yönelik saldırıları olan aşiretlerin durumuna ilişkin 1854 senesine ait olmak üzere verilen bilgilerden de anlaşllacağı üzere, öte taraf toprağına ve ahalisine yönelik olumsuz hareketlerin önüne geçilmesi için çaba sarf edildiği belirtilmiştir. Ancak Şehrizor Valisi'nin de açıkça ifade ettiği üzere, yaylak münasebetiyle İran tarafina geçen aşiretlerden bazılarının kötü adetleri üzere firsat buldukları sırada uygunsuz

\footnotetext{
${ }^{75}$ BOA., I. MVL., G. No: 11798 , B. No: II.

${ }^{76}$ BOA., I. MVL., G. No: 11798 , B. No: II.

${ }^{77}$ BOA., I. MVL., G. No: 11798 , B. No: II.

${ }^{78}$ BOA., I. MVL., G. No: 11798 , B. No: II.
} 


\section{F.Ü. Sosyal Bilimler Dergisi 2015-25/2}

davranışta bulunmalarının söz konusu olduğu vurgulanmıştır. Özellikle yukarıda bahsi geçen Kelâlî Aşireti ve İsmail Azîzi taifelerinin karıştığı olaylara ilişkin İran ahalisinden gasp ve yağma edilen eşya ve malların geri iadesi hususunda Süleymaniye Kaymakamı Münib Paşa'nın görevlendirdiği memurlar vasıtasıyla bahsi geçen eşya ve mallar tek tek tespit edilerek İran memurlarına teslim edildiği, karşılığında yazılı teslim-tesellüm belgeleri alındığı belirtilmiştir. Şehrizor Valisi, Şikâk Ali Ağa meselesinde kendisi ve aşiretinin Osmanlı'ya bağlı olmasına rağmen çıkardığı hadiseler sonrasında ortaya çıkan vaziyetin yakından takip edildiği bilgisini vermiş̧ir. Menkûr Aşireti Reisi Babür Ağa ve Köy-Sancak aşiretlerinden Sin/Sün aşireti Ağası Hızır Ağa'nın, İran tarafından celp olunduğu ve bunlara İran'ın iltifatlarda bulunarak kendi yanına çekmeye çalıştı̆g konusuna da tekrar vurgu yapılmıştır. ${ }^{79}$

Yine yukarıda da bahsi geçen Osmanlı'ya bağlı aşiretlerden birinin reisi iken uygunsuz hareketleri sebebiyle hakkında Sivas'a sürgün kararı çıkarılmış olan Mîr Azîz meselesinde de İran ile yapılan görüşmeler neticesinde iadesi hususunda bir kanaat uyanmışken, İran'ın meseleyi ağırdan aldığı anlaşılmıştır. Hatta Babür Ağa meselesinde olduğu gibi İran'in, Mîr Azîz'i Tahran'a çağırarak onu da taltif ve hediyeler ile kendi yanına çekmeye çalıştığı belli olmuştur. Bu durumdan son derece rahatsız olan Osmanlı Devleti, "bunların ve emsalinin cânîb-i Iran'dan celb ve te'minlerine çalışılması hususunda Iranlunun efkâr-ı muzırrası keyfìâtı beyân olunmuş olub" diyerek İran yönetimini suçlamıştır. ${ }^{80}$

Osmanlı yönetimi, bahsi geçen Kelâlî Aşireti ve İsmail Azîzi taifelerinin yaptıkları uygunsuz davranışlar sonrasında İran tarafından gasp edilen malların iadesi hususunda göstermiş olduğu gayret ve ciddiyet ortadayken, İran'ın Osmanlı aşiretlerine yönelik tam zıddı bir tutum içerisinde bulunmasının rahatsızlığını yaşamıştır. Osmanlı Devleti, sınır güvenliği noktasında ve iki taraf aşiretlerinin öte taraf toprağına, ahalisine zarar vermesinin önüne geçilmesinin önemine tekrar dikkat çekmiştir. Osmanlı açısından bu bölgedeki idarecilerin tembih edildiği ve asayişsizliğe izin verilmemesi hususunda bir irade ortaya konulduğu da beyan edilmiştir. İran'dan da Osmanlı'nın şikâyetçi olduğu konularda aynı hassasiyeti göstermesinin gerekliliği vurgulanmıştır. ${ }^{81}$

\section{SONUÇ}

Osmanlı ve İran devletleri tarih boyunca konumları, siyasi anlayışları, mezhebî farklılıkları ve hâkimiyet alanları bağlamında etki alanlarını genişletme gibi sebeplerle sürekli olarak çekişme içerisinde bulunmuşlardır. Bu çekişme mevzuları içerisinde de iki devletin sınır boylarında yaşayan göçebe bazı aşiretlerin çıkardığı sorunlar anlaşmazlık konularının önemli bir cephesini oluşturmuştur.

Bu aşiretler içerisinde Van, Bayezid, Hakkâri, Musul, Süleymaniye ve Şehrizor gibi bölgelerde meskûn olanlardan bazılarının göçebe bir özellik taşımaları, aşiretlere bağlı sıkıntıların ana unsurunu meydana getirmiştir. $\mathrm{Bu}$ sıkıntıların temelinde yatan husus ise, yaylak-kışlak münasebetiyle Osmanlı ve İran topraklarına yıl içerisinde gidip gelen bazı aşiretlerin hareketlilik haline bağlı olarak ortaya çıkan asayiş sorunları olmuştur. Nitekim bazı aşiretlerin yüzyıllardır süregelen bu geleneksel göçebelik hali onların varlıklarını sürdürmede ve ekonomik önceliklerinde kendilerince vazgeçilmez bir yapıyı oluşturmakla birlikte, bulundukları devletin topraklarında yaşayan yerleşik ahaliye yönelik gasp, yağma, adam öldürme gibi saldırıları ciddi asayiş sorunlarına da sebebiyet vermiştir.

Tarih boyunca Osmanl1-İ́ran sınırında yaşanan bu tip olumsuz hadiseler hem sınır güvenliğini tehdit etmiş hem de iki devletin bu meseleler dolayısıyla büyük gerginlikler yaşamasına zemin hazırlamıştır. Bilhassa XIX. yüzyılın ilk yarısı itibariyle 1821-1822 tarihinde yaşanan Osmanlı-İran savaşının sebepleri arasında, bazı aşiretlerin çıkardığı sorunlar varken, 1843-1847 yılları arasında

\footnotetext{
${ }^{79}$ Belgenin orijinal metninde bu husus; "haklarında mu 'âmelât-ı te'miniyye ve taltifiyye icra olunduğu” şeklindedir. Bahsi geçen bu belge 19 Cemaziyelvvel 1269 / 17 Şubat 1854 tarihlidir. BOA.,I. MVL., G. No: 11798, B. No: III.

${ }^{80}$ BOA., I. $M V L$., G. No: 11798 , B. No: III.

${ }^{81}$ BOA., I. MVL., G. No: 11798 , B. No: III.
} 
cereyan eden Osmanl1-İran gerginliğinin sebeplerinden biri de aşiretler meselesi olmuştur. $\mathrm{Bu}$ çerçevede de 1847 tarihinde imzalanan Erzurum Antlaşması'nın sekizinci maddesinde kapsamlı olarak aşiretler meselesi ele alınmıştır. Bu maddeye göre; bazı aşiretlerin çıkardığ 1 asayiş bozucu davranışların önüne geçme, hangi devlete bağlı olduğu belli olmayan aşiretlerin durumun belirleme -bunun için gerekirse kendi reylerine müracaat etme-, sınırların güvenliğini askeri tedbirlerle sağlama hususları yer almıştır.

Ancak 1847 sonrası yaşanan gelişmeler göz önünde bulundurulduğunda, İngiltere ve Rusya'nın da gözlemci devletler olarak içinde yer aldığı sınır tespit komisyonu çalışmalarında Osmanlı ile İran taraflarının uzlaşmasının pek de kolay olmadığı anlaşılmıştır. Zira iki tarafın iddiaları doğrultusunda ihtilaflı yerler meselesi kapsamında buralarda bulunan aşiretlerin durumu en çok tartışılan konulardan biri olmuştur. Bu meyanda 1850 sonrasında sınırlarda bazı aşiretlerin karıştığı yağma, gasp, adam öldürme gibi hadiselerin olması gerginliklerin devam edeceğinin işaretini vermiş̧ir.

Bilhassa Osmanl1-İran sınır bölgesinde bulunan Zilânlı, Şikâk, Menkûrî ve Kelâlî gibi aşiretlerin 1850-1854 yılları arasında çıkardığı sorunlar, meselenin büyüklüğünü göstermiştir. Bu aşiretler ve başlarındaki aşiret liderlerinin karıştığı hadiseler, asayiş ve güvenlik açısından büyük sorunlar oluşturmaya devam etmiştir. Bir yandan da Osmanlı ve İran yönetimlerinin sınır tespiti bağlamında bazı aşiretleri kendi yanına çekme niyeti taşıyıp buna göre hareket etmesi, sorunların kısa sürede çözümlenmesinin imkânsızlığını göstermiştir.

\section{KAYNAKÇA}

\section{Arşiv Vesikaları, Başbakanlık Osmanlı Arşivi (BOA)}

BOA, H.H., Dosya No: 4, Gömlek No: 105.

BOA, H.H., Dosya No: 1, Gömlek No: 8.

BOA, H.H., Dosya No: 1314, Gömlek No: 51255.

BOA, H.H., Dosya No: 1314, Gömlek No: 51256.

BOA, H.H., Dosya No: 444, Gömlek No: 22247.

BOA, A. DVN. MHM., D. No: 5, G. No: 35.

BOA., HR. MKT.UM., D. No: 29, G. No: 63.

BOA., A. MKT.UM., D. No: 62, G. No: 44.

BOA., I. MVL., D. No: 225, G. No: 7665, Belge No: 1-2-3-5-7.

BOA., I. MVL., G. No: 11798, B. No: I-II-III.

\section{Tetkik Eserler}

AHMED CEVDET PAŞA, Tarih-i Cevdet, C. XII, Tertib-i Cedid, Dersa'adet, 1309.

AYKUN, İbrahim, Erzurum Konferansı (1843-1847) ve Osmanlı-İran Hudut Antlaşması, Basılmamış Doktora Tezi, Atatürk Üniversitesi, Sosyal Bilimler Enstitüsü, Erzurum 1995.

BALCI, Ramazan, Osmanlı'nın Doğu Siyaseti, Yitik Hazine Yay., İstanbul, 2010

BALA, Mirza, “Kaçar” maddesi, İslam Ansiklopedisi (MEB), C, VI, Eskişehir 1997, s. 36-37.

Mehmed Hurşid Paşa, Seyâhatnâme-i Hudûd, Çevrimyazı, Alâattin Eser, Simurg Yay., İstanbul, 1997.

NASIRÎ, Muhammed Rıza, Nâsıreddin Şah Zamanında Osmanll-İran Münasebetleri (1848-1896). Basılmamış Doktora Tezi, İstanbul Üniversitesi Edebiyat Fakültesi, İstanbul 1977

SARIKÇIOĞLU, Melike, Osmanl-İran Hudut Sorunları (1847-1913), TTK., Yay., Ankara, 2013.

SERTOĞLU, Mithat; Mufassal Osmanl Tarihi, C. V, TTK. Yay, Ankara 2011.

SYKES, Percy M., A History of Persia, Volume, II, London, 1915. 
, "The Kurdish Tribes of the Ottoman Empire", The Journal of the Royal Anthropological Institute of Great Britain and Ireland, Vol. 38, Jul.-Dec., 1908, p. 451-486.

ŞÂNîZÂDE Mehmed Atâullah Efendi; Tarih-i Şânîzâde, C. III, İstanbul 1290.

ULUERLER, Sıtkı, XIX. Yüzyıl İlk Yarısında Osmanlı-İran Siyasi İlişkileri (1747-1848), Basılmamış Doktora Tezi, Fırat Üniversitesi, Sosyal Bilimler Enstitüsü, Elazı̆̆, 2009. 